\title{
LA OBRA LINGÜÍSTICA DE DON RAMÓN MENÉNDEZ PIDAL
}

\section{Menéndez Pidal y las ciencias del lenguaje. .}

I.o. Un día de abril de I955 había gran expectación en un amplio anfiteatro de la Universidad de Salamanca: se daba comienzo oficial y solemne al Quinto Congreso Internacional de Ciencias Onomásticas, y la enorme concurrencia de lingüistas, gramáticos y filólogos, esperaba impaciente que llegara, de un momento a otro, un invitado de honor. De pronto, apareció en el escenario un hombre bajito, más bien enjuto, protegido por un par de lentes en un rostro de finas facciones, con una calvicie compensada por una hermosa barba blanca: era don Ramón Menéndez Pidal, quien, en ese momento, recibía un aplauso, cerrado e impresionantemente prolongado, de todos los asambleístas.

Esta fue la primera vez que vi a este "milagro de hombre", como lo calificó en una ocasión Leo Spitzer. Y cómo no iba a ser un milagro, si se adentró en disciplinas tan complejas como la lingüistica, la gramática, la filologia, la historia, la literatura y el folklore, y en todas fue un maestro, según lo testimonian las obras, por lo mismo magistrales, que su genio produjo en cada una de ellas.

Mi propósito, en esta ocasión, es presentar, con sincera reverencia y profunda admiración, al lingüista, al gramático y al filólogo, creador de la ciencia lingüística española y propulsor, directa o indirectamente, de los estudios lingüísticos en la América española de nuestro siglo. Y cada vez que me sea posible, procuraré que hablen directamente el maestro y todos aquellos que, de alguna manera, aparezcan aquí relacionados con él, por el placer de escucharlos.

\section{I.I. El lingüista.}

I.I.o. Es difícil encontrar, dentro del amplio territorio de la lingǘstica, alguna zona no explorada por Menéndez Pidal, pero puede decirse que su mayor esfuerzo lo invirtió en desentrañar la historia de 
la lengua española, por lo que, dentro de la romanística, el título que más le conviene es el de hispanista. Don Ramón fue, pues, un hispanista, e inequívocamente, el más grande de todos.

I.I.I. Su labor entera gira de hecho en este sentido. En el campo de la dialectologia ha dejado un estudio fundamental sobre El dialecto lconćs ', con el que empieza en España, a juicio de Rohlfs, la investigación dialectal moderna ${ }^{2}$, y en el que se describen

los rasgos más relevantes del dialecto del primitivo rcino de Leén, en sus límites actuales y en los fenómenos lingülsticos [tanto fonéticos, como morfológicos y sintácticos] que le dan personalidad frente a los demás dialectos peninsulares:2.

La actualidad de esta obra, sólo en nuy pocos puutos superada, ha merecido una reimpresión en $I 962^{3}$, junto con sus Notas acerca del bable de Lena, de $1897^{4}$, la primera obra de Menéndez Pidal sobre el dialecto asturiano (él era de familia asturiana ${ }^{5}$ ). El tema del leonés le interesará de nuevo en I926, como lo testimonia su Prólogo a las Estampas de la vida en León durante el siglo $X$, de C. Sánchez-Albornoz ${ }^{\circ}$, y mucho más tarde, en I957, en que "Mundo Hispánico" (sept.) le publica un artículo sobre el Dialecto leonés central. Del dialecto aragonés trata de paso en Sobre el dialecto aragonés ', a propósito de la Colección de voces nisadas en la Litera, de B. Coll y Altabás y de Sobre voces aragonesas usadas en Segorbe, de C. Torres Fornes, y más ampliamente, en Origenes del español 8, donde Menéndez Pidal atiende también al asturiano, al

1 Revisla de Archivos, Bibliotecas y Museos, x906, XIV, pp. I28-I72 y 294-3II.

2 G. ROHUFS, Manual de filologia hispdnica. Guta bibliogrdfica, critica $y$ metódica. Bogotá, Inst. Caro y Cuervo, 1957, p. I62 (citado: Rohlfs, Manual).

- R. Menéridez Pidal, El dialecto leonés. Prólogo, notas y apéndices de Carmen Bobes. Oviedo, Inst. de Estudios Asturianos, 1962, p. 3 (cit.: Leonés).

- En el tomo II de la colección Asturias de Octavio Bellmunt y Traver, y Fermin Canella y Secades. Gijón, 1897, pp. 332-340.

- No aprendi desde la niñez los romances en una tierra empapada de ellos, en la arcaizante Asturiasi, ha confesado dou Ramón (CARMEN CONDE, Mentndez Pidal, Madrid, Unión Editorial, I969, p. 47; cit.: Conde, $M$. P.). También recuerda que en 1883, cuando ya teula catorce años, sus condiscipulos del Instituto del Cardenal Cisneros, en Mladrid, se burlabau de los asturianismos de su habla (ibid., p. 17).

- Madrid, Tip. de la Revista de Archivos, I926, pp. vii-xv. Otra ed.: Una ciudad de la I:spaña cristiana hace mil años. Estampas de la vida en León, 5." ed., Madrid, Rialp, 1966. Prólogo de R. M. P., pp. 8-14.

- Rev. de Aragón, 1903, año IV, t. II, pp. 242-248.

- Origenes del español. Estado lingütstico de la Peninsula Iberica hasta el siglo XI. MIadrid, RFE, Anejo I, 1926; refundida en "Obras Completas", VIII, Mfadrid, Espasa-Calpe, 1950; $4 .^{2}$ ed., 1956 (cit.: Origenes). 
leonés, al castellano y, muy particularmente, a los dialectos mozárabes. Pero, no contento con esto, quiso proporcionamos, además, los materiales para una eventual investigación dialectológica publicando unos Documentos lingiitsticos de España ${ }^{1}$, cerca de 400 documentos notariales de los siglos $\mathrm{xI}$ al xv, base de sustentación de los Origenes, y valiosísimos, entre otras cosas, para los ejercicios del estudiante universitario que tenga que estudiar gramática histórica española. Algunos de estos documentos formarán parte más tarde, junto con otros escritos medievales, de la excelente Crestomatía del español medieval ", "fruto del empuje creador de un maestro asistido por varias generaciones de discípulos" (t. I, p. viii).

I.I.2. Es sabido que los nombres de lugares, objeto de la to p on i m i a, frente a otros nombres, representan un elemento más constante que los hace inuy útiles para la historia de una lengua, pues conservan con frecuencia rasgos lingüísticos extinguidos en el lenguaje por la nivelación lingüística ${ }^{3}$; muestran la extensión del dominio del pueblo que los implantó y revclan sus intereses culturales, en relación con la flora y la fauna sobre todo, y son un claro indicio de sus creencias cuando tales denominaciones corresponden a hagiotopónimos. Con razón ha escrito don Ramón que

ula toponimia no es sólo la historia de los nombres propios más usuales en un idioma, pues encierra, además, uu singular interés como documento de las lenguas primitivas, a veces los únicos restos que de algunas de ellas nos quedan. Los nombres de lugar son viva voz de aquellos pueblos desaparecidos, transmitida de generación en generación, de labio en labio, y que por tradición ininterrumpida llega a nuestros oidos en la pronunciación de los que hoy continúan habitando el mismo lugar, adheridos al mismo terruño de sus remotos antepasados; la necesidad diaria de nombrar ese terruño une a través de los milenios la pronunciación de los habitantes de hoy con la pronunciación de los primitivos. $\mathrm{Y}$ esos topónimos arrastran consigo en nuestro idioma actual elementos fonéticos, morfológicos, sintácticos y semánticos propios de la antigua lengua, elementos por lo común fósiles e inactivos, como pertenecientes a una lengua muerta, pero alguna vez vivientes aún, conservando su valor expresivo, incorporado a nuestra habla neolatinaw."

1 I. Reino de Castilla. Madrid, Centro de Estudios Históricos, I9Ig.

2 Acabada y revisada por RAFalí LAPESA y MLARía SOLEDAD DE ANDRÉs. Madrid, Gredos, t. I. I965; t. II, I966.

3 Cp. RoHirs, Manual, p. 189.

- R. MIEníndez PIDar, Toponimia prerromanica hispana. Madrid, Gredos, I952, p. 5 (cit.: Toponimia). 
I.I.2.I. Pues bien, "todavía en la segunda mitad del siglo xrx el estudio de los nombres de lugar, carente de un método seguro, seguía siendo [en España] teatro de diletante fantasía [...], fue sólo Menéndez Pidal quien [ya en I906], reconociendo la alta significación del material toponímico, puso la toponimia sobre bases estrictamente cientificasn. (Rohlfs, Manual, p. I88). En los Orígenes del español, por ejemplo, las formas toponimicas documentadas constituyen kun importante instrumento para la reconstrucción del español preliterario y para la demarcación de los desarrollos regionalesn (ibid.). Pero no sólo aquí se ocupa de esta materia: son numerosos los artículos monográficos al respecto, "concebidos a modo de introducción a la historia de la lengua española", según palabras del propio don Ramón ${ }^{1}$. Por ejemplo: Sobre las vocales ibéricas e y $Q$ en los nombres topónimos ${ }^{2}$, doude pone de manifiesto una clara influencia ibérica subyacente en la toponimia aragonesa y catalana; Sobre toponimia ibero-vasca de la Celtiberia ${ }^{3}$ : Notas de toponimia", en que trata, entre otros, del nombre "Garona"; Sufijos atonos ${ }^{5}$, en que

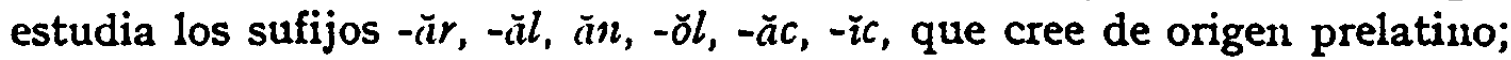
Sufijos átonos en el Mediterráneo Occidental ${ }^{6}$, en que, volviendo al tema del trabajo anterior, se refiere a los sufijos -ar, -an, -al, -ag, en la toponimia y en la lengua común, los cuales, aunque pertenecientes a lenguas de sustrato muy diversas, tienen usu principal trayectoria históricar no aislados, sino formando "un conjunto morfológico" (p. 36), "un sistema colerente, propio de las primitivas lenguas mediterráneas" (p. 55);

restos sufijos vivieron ajenos a la alta cultura latina, relegados humildemente al vocabulario rústico, para denominar vegetales y animales indoumésticos (gállara, cernicalo), para expresar nociones relacionadas con la vida campestre (chdtara, vargano, truébano); de ellos, pocos entraron en el caudal de la lengua más común y corriente (reldmpago, vdstago, sótano). El uso principal de estos sufijos es en la toponimia, siempre para designar lugares y ríos de poca inportancian (p. 54).

-En cuanto al significado, estos sufijos tienen un valor antiguo abundancial (Cuétara, Cuéllar, cienaga); tienen también valor imitativo de repetición, rapidez, fugacidad (ráfaga, trapala, pezpitalo); probablemente

1 Toponimia, p. 5 .

- RFE, 1918, V, pp. $22.5-255$.

3 Bol. de la Real Soc. Fascongada de Amigos del Pais, III. Homenaje a D. Julio de Urquijo. San Sebastián, 1950. pp. 463-467.

- Melanges de Philologie et d'Histoire offerts à M. Antoine Thomas. Paris, Champion, 1927, pp. 295-300.

- Origenes (I926). §6I bis; suprimido ell la 3.\% ed. de 1950.

- NRFH, 1953. VII, I-2. Homenaje a Amado Alonso I, pp. 34-55. 
tienen también un valor afectivo, cuasi diminutivo (luciérnaga, murciégalo); dado su uso principalmente vulgar, se aplican a conceptos peyorativos" (páparo, picaro, bichángano); pero, por lo común, esos valores particulares se desvanecen $y$ estos sufijos quedan sin siguificación uinguna: chscara pudo ser un colectivo de casca, pero hoy los dos vocablos vienen a ser sinónimos (p. 55);

Sobre el substralo mediterráneo occidental ${ }^{\text {; }}$ El sufijo -en: su difusión en la onomástica hispana ${ }^{2}$, representado, por ejemplo, en Aracena, Baena, Bailén, Jaén, Senén, Villena, etc.; Ligures y ambroilirios en Portugal ${ }^{8}$, en que defiende la tesis de que

nunas gentes designadas con el nombre nacional de $A$ ul b t o n e $s$, como los ligures (sic) de Italia, poblaron bastante densamente el norte de Portugal, la Galicia, Asturias y la parte occidental de León (Toponimia, p. I77);

"ambrones" que Kretschmer (1932) identifica con los "umbros» (ilid., pá-

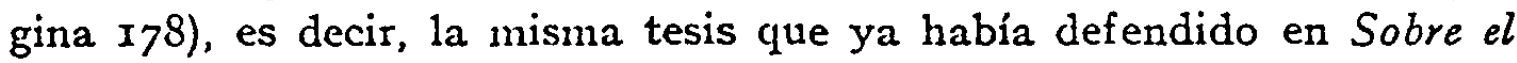
substrato mediterráneo occidental (v. supra), donde, en una apretada sintesis, nos dice que

utendremos que admitir que en España, además de los pueblos venido del Sur (capsienses e iberos) y de los del Norte (cantábrico-pirenaicos) hubo otro venido de Iuropa [Central] y extendido hasta el extremo Sur de la Penúnsulay (ibid., p. 8I):

los "ambrones", que acaso "mo eran sino ilirios indoeuropeos, mezclados con un fuerte substrato mediterráneon (ibid., p. 9I); El elemento -obre en la toponimia gallega "(Menéndez Pidal era gallego); La etimologia de Madrid y la antigua Carpetania ${ }^{5}$, en que, frente a un origen árabe, o latino, o germánico, o griego, aduce un posible origen céltico en la forma hipotética MAGETORITO, compuesto de mago-, mageto-, 'grande', y ritıl-, 'vado, puente'; es decir: 'vado largo' o 'puente grande', "señalándonos ya en lo antiguo la particularidad notable del Manzanares, que, a pesar de ser río muy chico, exige un puente demasiado largon, conclusión ésta, sin embargo, objetada más tarde (I954) por Jaime Oliver Asín en El nombre Madrid 6 , en que (se demuestra que la capital de

1 ZRPh, 1939, I,IX, 1). I89-206.

2 Emérila, I940, VIII, pp. I-30.

3 Lev. da Facullade de Letras. Lislooa, 1943, X, 1p. 3-I 5.

- Cuadernos de Estudios Gallegos. Madrid, 1946, fasc. V, pp. I-6.

- Arbor, 1946, V, pp. 355-56.

- Arbor, 1954, XXVII, pp. 393-426. 
España en la época musulmana bilingüe tuvo dos nombres: Matriche y Macherit, de los cuales el uno mozárabe (Matriche) se refiere a un antiguo canal subterráneo "matriz" (en Andalucia todavia Almatriche), mientras que el otro (Macherit) sería una exacta traducción del to-, pónimo mozárabe al árabe vulgar machrá 'venaje de agua' (Rohlfs Mantual, p. I96, nota), es decir: conjunto de manantiales o venas de agua que dan origen a un río; Murcia y Mortera, dos topónimos hidrográficos ${ }^{1}$; Toponimia mediterránea y toponimia valcnciana primitiva ${ }^{2}$, y otros trabajos, recogidos en su mayoría en Toponimia prerrománica hispana (v. supra 1). 227, 11. 4), alguno de los cuales, a decir de Rohlfs, "no satisfacen ya el estado actual de la investigación" "; pero tienen el mérito indiscutible - pensamos nosotros- de haber sido los primeros verdaderamente científicos en el mundo hispánico, de haber despertado el interés por esta disciplina y de haber impulsado su desarrollo.

De hecho, la toponimia aparece en la mayoría de los trabajos de Menéndez Pidal, y siempre como un instrumento metodológico valiosisimo para dilucidar algún problema de la biografía de la lengua española, y así hasta los últimos años de su casi centenaria vida, como lo prueba su polémico ensayo Dos problcmas iniciales relativos a los romances hispánicos 4, en que, insistiendo en la colonización suditaliana de España ${ }^{5}$, tema tratado monográficamente en $A$ propósito de $-l l-$ y $-l-$ latinas. Colonización sıditálica cn España ${ }^{6}$, concluye perentoriamente que

rel gran grupo de lenguas hispánicas, catalán, aragonés, castellano, y leonés, es una continuación del latín osco-sabino, osco-lucanon (p. cxroxviii).

I.I.2.2. E1 contenido de los trabajos citados -y a veces hasta su sólo título- nos muestra con claridad que la toponimia le sirvió a don Ramón principalmente para plantear y resolver algunos problemas de sustrato.

1 Filologia. Buenos Aires, 1951, III, pp. I-5; reprod. en Estudios de Lingïistica (v. infra p. 236, n. 5), pp. 73-83.

2 Actas y Memorias, I (1953), pp. 6I-75, VII Congreso Internacional de Lingüistica Románica, Univ. de Barcelona.

3 RonLFs, Manual, p. IgI.

- Enciclopedia lingülstica hispánica, I. Madrid, C. S. I. C., I960, pp. xxviicarviiii (cit.: Encicl.).

- "Los topóniumos itálicos cn Iespaña pertenecen todos al sur de Italiav (ibid., página LIX).

- BRAE, 1954, XXXIV, pp. ז65-216. 
- Tin el fondo, el problema del sustrato es el de hasta qué punto un pueblo puede abandonar su lengua para tomar, por pérdida de su independencia, asimilación cultural, extinción de su personalidad politica, la de otro pueblo. Las formas de la lengua anterior no son nunca sustituidas completamente, y queda siempre en los nombres de lugar, a veces en los de persona, en ciertos nombres que podemos llamar típicos (de fauma y flora, vestidos, comidas, cosas domésticas, agrícolas, de oficios, etc.), la huella de la lengua anterior. Por otra parte, queda en la misma lengua aprendida, en fonética, semántica, sintaxis, la señal de la olvidada: ciertos conceptos se explican con la palabra nueva, pero en una extensión o especialización que desconocía ésta en su estado originario, ciertos sonidos se adaptan a la fisiologia heredada y desarrollada por la costumbre, etc.

Se podria comparar en la teoria del sustrato a la nueva lengua con una inundación que cubre lo que ocupó el limo de la lengua antigua, pero dejanclo ciertas partes energidas, otras sobrenadando, otras finalmente difunclidas y disueltas, dándole a la lengua invasora un color nuevon. 1

I.I.2.2.I. Muy buena la imagen, pero no olvidemos que, ante tal o cual innovación lingüística, o ante la explicación de un fenómeno de suyo difícil de explicar, los especialistas, como es de conocimiento general, se han organizado en dos bandos irreconciliables: uno, el de los que buscan -y creen hallar - la solución en la levadura del sustrato, y otro, el de los que la buscan o en el árbol genealógico a que pertenece la lengua que plantea el problema, o - los menos- en la trama y urdimbre de esta lengua. Ya sabemos que don Ramón, aunque sin fanatismo, hace causa común más bien con los primeros.

I.I.2.2.2. I, a dificultad mayor que los antisustratistas suelell alegar para no aceptar como sustrático un determinado fenómeno - según el breve pero categórico artículo Modo de obrar el sustralo lingüístico ${ }^{2}$-, es

Auna dificultad cronológica: los documentos que se consigue allegar sobre el cambio lingüistico suelen ser tardios, de una época en que ha desaparecido hace mucho la lengua de sustrato a la que tal cambio puede ser atribuidow (pp. I-2),

dificultad que se complica con la idea sustentada por los mismos de que "las leyes fonéticas obran de una manera rápida y absoluta» (ibid., p. 2).

"Iis en verdad imponente -comenta don Ramón- este argumento cronológico. Si la lengua de substrato ha desaparecido lace siglos cuando llega a aparecer el fenómeno atribuido al substrato ¿cómo salvar esa distancia? La explicación dada por Ascoli, las "reacciones étnicas", las pre-

1 Antono Tovar. Lingüistica y filologia. Sil siluación actual. Madrid, Rev. de Occidente, 1944, pp. 80-81 (cit.: Tovar, Ling. $y$ filol.).

2 RFE, 1950, XXXIV, p1). I-8 (cit.: Modo). 
disposiciones oralesn, exigen una interpretación. Bertoni, en su Breviario di neolinguistica (de 1925), cree que tales reacciones étnicas no son nada racial, sino simplemente un factor históricon. Precisando decir algo más concreto, Tagliaviui en 1934 explica esas reacciones por "ciertas tendencias, especialmente fonéticas, que se pueden heredar y reaparecen a distancia de muchas generacionesw. En análogo sentido y con superior claridad se expresa A. Meillet cuando habla de "una acción diferida del sustraton [...], racción profunda de tendencias hereditariasn; la lengua primitiva de un pueblo, cuando es sustituida por otra, no obra sobre ésta de un modo inmediato, sino ‘por efecto lejano de hábitos adquiridos, transmitidos por herencian. Pero contra explicaciones de este tipo se declara decididamente Meyer-Lübke en 1924 [...]; se niega en absoluto a pensar con raquellos que creen que en la evolución lingüistica existen fuerzas latentes, las cuales pernunecen inactivas a través de muchas generaciones, hasta que después, en un mowento dado, salen a luz». Yo, concluye Meyer-Lübke, no soy capaz de ir por semejantes caminos" (ibid., p. 3). "X es bien dificil -confiesa Menéndez Pidal- no compartir esta repugnancia del maestro. La herencia de los hábitos adquiridos es cosa muy dudada y muy dudosa en todos los terrenos. Es necesario buscar otra explicación más comprensible. En vez de una tendencia lereditaria diferida, en vez de una fuerza la t e $n$ t $e$ in a c $t$ i v a que a larga distancia resurge a la actividad, pensemos en una tendencia lat ente a ctiva, operando lentamente, oculta, inadvertida durante varios siglos ell que esa tendencia coeriste con la tendencia dominante que es la únicamente ostensible o manifiestas (ibid., p. 4).

$\mathrm{Y}$ así llegamos a la formulación de su teoría del es tado la te $\mathrm{n}$ te, tan grata a don Ramón desde los Origenes del Español, por lo menos, y a la cual fue fiel durante toda su vida, hasta el punto que, a los 94 años de edad, todavía encontró tiempo para publicar El estado latente en la vida tradicional ${ }^{1}$, teoría que iuvalida la objeción cronológica:

"La convivencia prolongada, durante varios siglos, de una forma de substrato con otra propia de la lengua adoptiva dominante, es un estado lingüistico esencial que no se tiene en cuenta al formular el argumento fundado en la fecha tardja de los primeros documentos hallados, pensando que entonces hubo de nacer y consumarse el cambio fonético que esos documentos revelan. No se considera que esos primeros documentos representan sólo el aflorar de un fenómeno existente hace mucho tiempo. La duración multisecular de una evolución fonética es noción que debemos al testimonio de los documentos pertenecientes a la época preliteraria (ibid., páginas 5-6).

-Hay que desechar -entonces- la falsa creencia de que los cambios lingüisticos se realizan rápida y casi momentáneamente, a modo de una revolución decidida y arrolladora; muchos errores se cometen en la cronologia relativa de los fenómenos fonéticos por seriarlos simplistamente como etapas succsivas que no se entremezclan ni superponen sus fenómenos umas con otras: (Origcnes, p. 535).

- Revista de Occidente, 2. "época, 1963, II, pp. I29-I53. 
hecho sobre el cual don Ramón ha llamado repetidas reces la atención. He aquí una de ellas, en que realza el tradicionalismo como rasgo inherente a la vida de nuestra lengua y demás instituciones culturales:

"Hay, evidentementc, en el desarrollo de cada sonido tendencias colectivas que muchas veces llegan a convertirse en normas generales, en leyes fonéticas regulares. Pero debe añadirse que la constitución de una de esas leyes no es obra de un momento, sino de un lapso de tiempo muy prolongado. (ibid., p. 532).

"Se ha buscado el principio cle la evolución del lenguaje en cada cambio de generación; pero las generaciones no cambian cada veinte o cada treinta años, sino que calla dia nacen y se renuevan imperceptiblemente. Cualquicr cambio en la actividad colectiva tradicional, lo mismo respecto al lenguaje çte a la canción popular, que a la costumbre juridica, etc., se fuucla en el hecino de que muchas generaciones c o usecutivas participan de una misma idea innovadora y la van realizando persistentemente, a pesar de pequeñas variantes en el modo de concebirla; constituyen una traclición nueva, en pugna con otra tradición más antigua" (ibid.). . Ia duración del cambio fonético suele ser extraordinariamente larga, multisecular, por lo mismo que la tradición que hay que vencer es la más fuerte de toclas, como arraigada en la inmensa repetición cotidiana del acto colectivo del lenguaje. I os 300 años señalados por Saussure como caso notable de duración para la propagación de un cambio lingüistico son todavia poca cosa en muchos casosn (ibid., p. 533). ${ }^{1}$

Pero desechada "la falsa creencia de que los cambios lingüísticos se realizan rápida y casi momentáneamente", y con ella la "dificultad cronológica" concomitante, hay que salvar todavía otra antes de aceptar la existencia de un "estado latente»: ¿Cómo es posible "que un fenómeno lingüistico exista durante siglos y a la vez permanezca completamente oculto a la vista de cuantos en todas las épocas pueden estar interesados en observarlos»? (Modo, p. 6). La respuesta es muy simple, por lo empírica, y la da el propio Menéndez Pidal:

"Infinidad de hechos sociales vivieron completamente inobservados. Uno citaré que tengo de muy repetida experiencia personal. El canto tradicional de romances en muchas regiones del dominio hispánico vivió, desde la segunda mitad del siglo xvm hasta comienzos del xx, no sólo inobservado, sino negado" (ibid.). "La causa de este vivir tan encubierto es que el canto del romance oral vino a ser menospreciado en la sociedad culta y literaria conforme avanzaba el siglo xvir $y$, quedando relegado a las clases más incultas, no llegó a merecer atención uinguna a los escritores que porlrian consignar alguna noticia a él referente" (apud Conde, $M . P .$, p. 93). "Pues

2 Véase $1:$ Dr: SaUssure, Curso de Lingïística general, Buenos Aires, Losada, 1945, pp. 328-329 (cit.: Saussure, Citrso). 
si la existencia de tocla una copiosa poesía romancista cantada llega a ser no sólo desatendida, sino expresamente negada por los informantes preguntados, nada de extraño puede tener el que un fenóneno fonético de substrato, condevado por las capas más cultas de la sociedad, no encuentre maclie que lo manifieste cul los siglos anteriores al $\mathrm{x}$ o al XI, ya que entonces lo muy poco que se escribe es en latin, salvo raras muestras en latín vulgarizante, y 110 lay gramáticas de vinguna clase que pudieran preocuparse de anotar vulgarismos (Modo, p. 6).

En suma,

-para saivar la objeción cronológica, esto es, la distancia entre la desaparición de la lengua de substrato y la aparición de los primeros testimonios, bastan esos dos conceptos históricos: la plurisecular duración de un proceso lingüistico gel estado latente en que perdura toda innoración antes de hacerse manifiestan (ibid., p. 7).

Por lo tanto,

"para suplir nuestra carencia de datos durante varios siglos no pensenos en una acción diferiula, no eu una fuerza latente inactiva cuya operación sólo reaparece muy tarde; pensemos sólo en un estado de actividad latente, un uso lingüfstico propio del idioma socialmente desconsiderado, uso que primero se introduce subrepticiamente en la lenigua adoptiva como un bajo defecto, rechazado en absoluto por todo hablante culto, uso que después va ganando poco a poco el gusto de las generaciones sucesivas, a través de los siglos, en reacciones de llaneza y desafectación, llegando a ser tolerado entre la gente culta, liasta que al fin se hace preponderante y aun exclusivo (ibid, p. 8).

Etapas, éstas, que quedan muy bien ilustradas, con un ejeinplo entre muchos, en la sustitución de la $[f]$ inicial por $[h]$, y subsiguiente pérdida, en Castilla, donde

res un fenómeno primitivo hijo de la influencia ibérica, de los dialectos indigenas vecinos al vasco ${ }^{1}$. En los perfodos primitivos, la repugnancia por la $f$ tiene sólo campo entre la gente más dominada de inculto iberismo, refractaria a la docta romanidad; hasta el siglo $\mathrm{xar}$, la $h$ en vez de $f$ (o la supresión de ésta) se halla $\mathrm{r}$ e $\mathrm{c}$ h a $\mathrm{z}$ a d a enérgicamente de la literatura; la represión purista apewas deja aparecer $h$ en alguna cacografia que otra,

1 R. MLentédeez Pidal, Mantal de Gramática Histórica Española, 7.3 ed., Madrid, Espasa-Calpe, 1944, $\S 38_{2}$ (cit.: Manual). Esta tesis, como se sabe, ha sido impugnada por Alartinet, para quien ningún idioma que carezca de $|f|$ lo sustituiria por una consonante laringea (Emmio ArARcos, Fonología española. tercera ect., Madrid, Gredos, r96r, p. 247). Según Rolrr.FS, sseguro es sólo que [el fenómeno $\mathrm{f}>\mathrm{h}$ ] se extendió partiendo de un territorio muy pequeũo cercano a la frontera lingiilstica vasca" (Ronr.rs, Manual, p. I36). 
$y$ asi el fenómeno permanece en esta $d$ o 1 a t e $n$ te muchos siglos. Tin los siglos XIV y XV, la eliminación de la $f$, bastante extendida ya por la lengira familiar de ambas Castillas, alcanza otro estado diverso: llega a ser t o l e r a d a en la literatura de ambas regiones, como expresión más desafectada y llana. Iin el siglo xv la condición de este cambin fonético progresa notablennente, yues llega a ser p r e ponde r a nte. Jin el siglo Xvr se hace la $h$ de uso e $x$ cl u s i v o en la literatura castellana; lo que antes era una nera tendencia innovadora se ha generalizado al fin, aunque lentisinamente, hasta convertirse en una ley general para la lengua literaria, como hacia mucho que lo era para la lengua rústica del norte de Castillan

Is t a d o 1 a te n te, entonces, mirando el problema desde la lengua literaria, "docta", "purista" y obstinadamente conservadora; pero e s t a do in a $n$ if i e s t o, rigente, desde el punto de vista de la lengua oral de los estratos socioculturales inferiores, libres del "fetichisno de la letra".

I.I.2.2.3. Aceptada la existencia de lenguas de sustrato, don Ramón se da a la tarea de investigar los e le mentos for á neos en el español, tanto en los Origenes y en su Manual de Gramática Histórica Española, como en una serie de estudios monográficos, algunos de los cuales ya han sido señalados.

Es evidente que, para el conocimiento lingüístico de la Península Ibérica, el estudio más apasionante en este sentido es el de "la influencia de las le nguas i béricas, no indoeuropeas, que, salvo el vasco, perecieron con la romanización de Españas (Manual, § 41), influencia "aún muy oscura por ser aquéllas poco conocidas» (ibid.), no obstante "el hecho único en todo el sur y occidente de Europa de tener nosotros todavía una lengua [-el vasco justamente-] anterior no sólo a la romanización, sino a la llegada de los indoeuropeos" (Tovar, Ling. y Filol., p. I20).

Ya hemos visto que don Ramón enfocó el tema parcialmente en Sobre las vocales $\& y$ g en los nombres toponimicos y en Sobre toponimia ibero-vasca en la Celtiberia; pero también le dedicó un trabajo de conjunto: Influjo del elemento vasco en la lengua española ${ }^{2}$, y estimuló y guió, con sus sabios consejos de siempre, la investigación en profundidad del vascuence, ya en I920, en una conferencia publicada al año siguiente

1 Origenes, pp. 533-534. Lo mismo en el caso de la pérdida de $t$ final en la tercera persona de las formas verbales, que tardó inuchisimo en generalizarse, pues "la reacción cultista [el cultismo "reaccionario»] obró tenazmente para mantener o restaurar este sonidon (ibid., p. 35r).

2 En Crónica del 11 I Congreso de Estudios Vascos [1922], San Sebastiáu, Soc. de Iistudios Vascos, 1923, 1p. 27-31. 
con el título de Introducción al estudio de la lingiiistica vasca ${ }^{1}$, donde bosquejó lo que todavía hoy es "un programa lleno de atractivos para generaciones de investigadores" ${ }^{2}$ : I) elaborar una historia de la lengua vasca, 2) 10 eliminar lo románico de los diccionarios vascos, hechos con un falso prurito de purismo, 3) dar importancia a la toponimia ${ }^{3}, y$ 4) dársela igualmente a la geografía de la lengua vasca.

A los 93 años de edad aún seguía don Ramón preocupado de este asunto, como lo prueba su En torno a la lengua vasca, un tomito de 144 páginas".

I.I.3. A la a $11 \mathrm{t}$ r o p o n im i a, Menéndez Pidal ha dedicado también algunos estudios, como Menendus s, en que da cuenta de la génesis de su primer apellido, kejemplo metodológico de investigación onomástican ${ }^{\circ}$, donde se prueba que tal nombre es de origen germánico, el que se remonta, en la alta Edad Media, al de San Ermenegildo, hijo del rey Lcovigildo, muerto inártir en 585 , "el primer personaje famoso que se llama así en Lispañan (ibid., 1). 364): Ėrmenegildus > Menigilclus $>$ *Menegindus $>$ Menendus, $y$, en colaboración con Antonio Tovar, Los sufijos españoles en -z, y especialmente los patronimicos?, destinado a establecer la procedencia de la terminación -ez en los apellidos, con lo que completa así la explicación del suyo. En I 965 publica un breve estudio sobre Onomástica inspirada en el cullo mariánico ${ }^{8}$, producto de unas «indagaciones y notas sueltas tomadas [...] en 1935 y I936", las que muestran que de

las advocaciones varias usadas ell el culto de la Virgen Maria, unas proceden de los misterios de su vida, fijados desde los primeros siglos de la Iglesia (la Asunción, la Purificación, la Soledad); otras se refieren _a los ligares del culto (de Iroreto, del Carmen, de Guadalupe, etc.); otras aluden al mismo culto y protección implorada (del Rosario, del Consuelo, etc.). (página 9).

1 En Cursos de Melodologia y Alta Cullura. Curso de Lingü̈istica, Barcelona, Sociedad de Estudios Vascos, 1921, pp. 7-33.

2 TOVAR, Ling. y Filol., p. 82.

3 "Gran parte de la historia del vasco está archivada en los nombres de lugar, donde se conservan fósiles de la lengua primitiva que no dejaron de sí otra memoria alguna (Toponimia, p. 46).

- Col. Austral, Buenos Aires, Espasa-Calpe, 1962.

s NRFH, 1949, III, pp. 363-37I; reprod. en Estudios de lingïistica, Col. Austral, Madrid, Espasa-Calpe, 196r, como Menéndez, Méndez, Mendes», pp. 33-57.

- RoHLiss, Mamual, p. 195.

7 BRAE, I962, XIII, 1p. 371-400.

- Ciuaternos del idioma. Año I, nún. I, Buenos dires, Lidit. Codex, I965, 1). y-10. 
I.I.4. La ge og rafía ling üistic a, encargada de fijar en el espacio los fenómenos lingüísticos ", señalando las áreas en que éstos ocurren, mediante la determinación de sus límites, expresa sus resultados, como se sabe, en mapas, cuyo conjunto constituye el atlas lingüístico, el primero de los cuales cronológicamente es el Allas lingiístico del norle y contro de Alemania, de G. Wenker, del que sólo apareció un fascículo en I88r. Ahora bien, desde esta fecha lasta la aparición del Atlas linguistic de Catalnnya en I923, del padre Griera, discipulo de Gilliéron, habían pasado 42 años y habían visto la luz en Europa casi una decena de atlas lingüísticos. Puede decirse, pues, que España se incorporó relativamente tarde a este movimiento, y aún limitado a Cataluña. Una vez más fue necesario el impulso creador de Menéndez Pidal para que no ya una zona, sino toda la Península fuera investigada lingǘsticamคnte con vistas a cartografiar los resultados. En efecto, gracias a su iniciativa y entusiasmo, en I 923 se dio comienzo, en la Sección de Filología del Centro de Esstudios Históricos de Madrid, a los trabajos preliminares para el Atlas Lingiiislico de la Peninsula Ibérica (ALPI), encomendados al entonces Director del Laboratorio de I'onética, 'Tomás Navarro, encargado del Allas ya en I9Io ${ }^{2}$ y quien contó, entre otros, con la inapreciable colaboración de Américo Castro y de Amado Alonso. Pero a cinco años de haberse iniciado sistemáticamente las encuestas preliminares, estalló -en I936- la Guerra Civil. Interrumpidas las labores por este motivo, los materiales fueron trasladados a Valencia, luego a Barcelona, después a París y finalmente a Nueva York, siempre custodiados por Navarro, hasta que, a principios de I95I, volvieron definitivamente a Madrid, al C. S. I. C., responsable, ahora, de la edición de la obra. Aunque en 1956 se pone fin a la recolección de materiales, el ALPI vino a ser publicado sólo en I962, y no en su totalidad, pues únicamente ha visto la luz un primer tomo, dedicado a la fonética. Es de imaginar la alegría que sentiría don Ramón al ver realizada por fin una idea suya alimentada por más de 50 años.

I.I.4.I. Su conocimiento de la geografía lingüística y su interés por ella, se hacen evidentes en más de uno de sus trabajos, pero basta recordar que ya en los Origenes del español ${ }^{3}$, aplicando los métodos o no m a sioló g i cos de Gilliéron, elaboró un largo apartado (\$\$ 8385) sobre geografía léxica, en que se vive con don Ramón la

1 "Iil estudio de los caracteres dialectales ha sido el punto de partida de los trabajos de cartografia lingüistica (SAUSSURE, Curso, p. 321).

2 Leonés, p. 153

3 Ver Origenes, 4." ed. (1956), pp. 388-413, por ejemplo. 
gran aventura de perseguir no sólo por tierras peninsulares, sino en general románicas, las diversas denominaciones que, por una u otra razón, los hablantes han ido dando a unas mismas cosas; ensamblaje de upalabras y cosas" realizado por el sentido popular y magníficamente revelado y explicado por el don heurístico de nuestro autor.

Puede decirse que rincluso la ge og a fía folk 1 ó ric a, que él practicó ${ }^{1}$ con métodos distintos que los de Krohn y Ohrt, era, entre otras cosas, la proyección cartográfica del romancero tradicional ${ }^{2}$.

I.I.4.2. Un problema muy de la geograffa lingǘstica y casi siempre

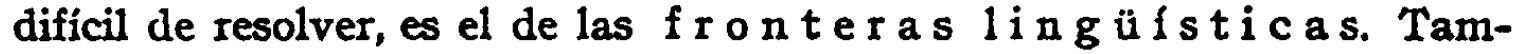
bién aquf Menéndez Pidal dijo su autorizada palabra. Son testimonio: Pasiegos $y$ vaqueiros. Dos cuestiones de geografia lingüistica ${ }^{3}$, de interés para el leonés; Sobre los limites del valenciano 4, y Sobre A. Griera: La frontera catalano-aragonesa ${ }^{5}$, que censura "las tentativas de Griera de fijar los límites lingüisticos sirviéndose del material acumulado a base de un cuestionario [y] combate también la idea de que la frontera catalano-aragonesa hubiera sido determinada por los límites que tenía al comenzar del siglo xi el obispado de Roda y el condado de Ribagorzan (Iordan, Ling., p. 404, 11. 258).

I.I.4.3. En fntima relación con el problema que plantean las lenguas colindantes en la determinación de sus fronteras, fijadas mediante «líneas isoglosemáticas» ${ }^{B}$, está el de explicar cómo se producen los fenómenos de diferenciación 1 ingüistica que vienen a justificar la existencia de tales fronteras. Se sabe, al respecto, que la teoría más generalizada fue la de la separación geográfica de los habitantes por migración, pacífica o no; pero

thay que guardarse de atribuir a la separación lo que se puede explicar sin ella. Fse es el error que cometieron los primeros indoeuropeistas. Situados ante una gran fanuilia de lenguas que se habian hecho muy diferentes unas de otras, no peusaron que eso podia haberse producido de otro modo que por fraccionamiento geográfico. $L_{a}$ imaginación se representa unás fácilmente lenguas distintas en lugares separados, y para un

1 R. MENÉndez PIDAL, Sobre geografía folklórica. Ensayo de un método. RFE, I920, VII, pp. 229-338; reprod. como Anejo LX de la $R F E$, Madrid, r954.

2 I. IORDAN, Lingüística románica. Madrid, Ediciones Alcalá, Ig67, pp. 443-444 (cit.: Iordan, Ling.).

${ }^{3}$ Archivum, 1954, IV, pp. 7-44.

- Iin el Primer Congrès Intern. de la Llengua Catalana [1903], Barcelona, I90S, pp. 340-344.

- Estudi geografico lingïistic. RFE, I9I6, II, p1. 73-88 (cit.: Griera).

- Saussure, Carso, p. 323. 
observador superficial ésa es la explicación necesaria y suficiente de la diferenciación. Y algo más: se equipara la noción de lengua a la de nacionalidad, y ésta explicaba a aquélla; así se imaginaba a los eslaros, los germanos, los celtas, etc., como otros tantos enjambres salidos de una misma colunena; esos pueblos, separados por migración del tronco primitivo, Inabrian llevado consigo el inclocuropeo comin a otros tantos territorios diferentesi (ibid., pp. 332-333).

Pero si esto no ocurrió así, es decir, en concordancia con la $\mathrm{S}$ t a m mb a u m th e o ri e, la teorfa del árbol genealógico de Schleicher, ¿qué explicación cabe entonces?

*In 1877 una obra de Johannes Schmidt, Die Verwandtschafts-Verhältmisse der Indogermanen ', abrió los ojos a los lingüistas al inaugurar la teoria de la continuidad o de las ondas (W e ll e n th e ori e). Entonces se comprendió que el fraccionamiento sobre un mismo territorio basta para explicar las conexiones reciprocas entre las lenguas indoeuropeas, sin que sea necesario adinitir que los diversos pueblos hayan dejado sus posiciones respectivas; las diferenciaciones dialectales se han podido y debiclo producir antes de que las naciones se hayan dispersado en direciones divergeutes. Así la teoría de las ondas no sólo nos da una visión más acertada de la prehistoria del indoeuropeo, sino que también nos ilustra sobre las leyes primordiales de todos los fenómenos de diferenciación y sobre las condiciones que rigen el parentesco de las lenguas". (Saussure, Curso, p. 333).

Como se ve, y no obstante ser Schmidt discípulo de Schleicher, no siguió, en el tema que nos ocupa, las ideas del maestro, sino las de Schuchardt, quien sólo algunos años antes había propuesto poco más o menos lo que luego propondría y desarrollaría él, es decir:

uremplacer l'image de l'arbre généalogique par celle des ondes propagées à la surface de l'eau par la chute d'une pierre" ": "Inıginémonos la lengua en su unidad como una superficie de agua - nos pide Schuchardt-; ésta se pone en movimiento porque en diversos lugares se forman círculos concéntricos, cuyos sistemas, nuás o menos extensos según la intensidad de la fuerza motriz, se entrecruzan" (apid Jordan, Ling., p. 82).

1 Según otros autores fue publicada en Weimar, 1872 , con el nombre de Die Verwandtschaftsverhältnisse der indogermanischen Sprachen. Véase, por ej., DEMTrkio Gazdaru, Controversias y doctmentos ling ïisticos, Buenos Aires, Univ. Nacional de la Plata, 1967, p. I58 (cit.: Gazdaru, Controv.), cuyo cap. II, "A propósito de Stammbaumtheorie y Wellentheorie" (pp. I44-I64), se refiere ampliamente y de un modo critico a las controversias originadas por ambas teorias.

2 En Der Vokalismus des Vulgärlateins, III, Leipzig (1868), p. 32.

3 M. Lreroy, Les grands courants de la linguistique moderne. Paris, P. U. F., I963, pp. 5I-52 (cit.: Leroy, Courants). 
Pero, para darle al César lo que es del César, hay que agregar que "en verdad, la me r a c o m p a r a c i ó n de Schucliardt no es lo mismo que la teoria completa y orgánica de Schmidt" (Gazdaru, Controv., p. I6r; el espaciado es mio).

Aliora bien, frente a estas dos teorías resalta la postura teórica, siempre "modernan, de Menéndez Pidal, cuando, para explicar por qué las áreas geográficas delimitadas lingüísticamente son independientes, escribe que

wobedecen a irradiaciones parciales dentro de un medio lingüistico relativamente homogéneo, capaz de ser afectado por esta especie de moviwientos ondulatorios que se propagan, cada uno según un impulso independiente, a diversas distancias y en diversas direcciones: (Griera, p. 77).

Loable decisión entre dos teorias divergentes ${ }^{1}$, por más que "cette W e 11 e n t h e o r i e, tentative pour se représenter comment les choses out dû se passer, laissait sans doute encore beaucoup de faits dans l'ombre et ne soupçonnait pas la complexité effective des évolutions linguistiques, mais les études ultérieures ont montré qu'elle était fondée pour une part non négligeablen (Leroy, Courants, p. 52).

I.I.5. A la e stilis ti ca, en cuanto estudio del modo individual de hacer uso de la lengua común, Menéndez Pidal ha contribuido particularmente con algunas investigaciones idiolectales, como La lengua de Cristóbal Colón ${ }^{2}$, El estilo de Santa Teresa ${ }^{3}$, El lenguaje en Lope de Vega", y de un modo más sucinto, con las diversas presentaciones de los autores recogidos en su Antologia de prosistas españoles 5.

I.I.5.I. En el primero de estos estudios, al analizar la 1 e $\mathrm{ng} \mathrm{u}$ a us a d a o r Colón, don Ramón encuentra la confirmación dè que

1 "Lista teoria de las ondas se opone a la de las migraciones sin excluirla necesariamente (SAUSsURe, Curso, p. 333). Un intento de conciliarlas es el de H. GüNrERr, segúu se desprende de estas palabras suyas: Aubas imágenes, la del árbol y la de las ondas, son igualmente idóneas, con la diferencia que la primera es como una sección lougitudinal y la segunda una sección transversal en la gran construcción iudoeuropea" (apud GAZDARU, Controv., p. 160).

$2 B H i .$, 1940, XIII, pp. 5-28.

3 Escorial, NIadrid, I9.4I, Pp. I3-30; reimpresa (en forma ampliada) con la anterior y algunos apéndices en Colón, pp. I29-153, y, sin notas ni apéndices, en España, II, pp. I60-I 76 .

- Mr. P., España y su historia, II, Madrid, Minotauro, 1957, pp. 336-353 (cit.: Espania, II).

s Col. Austral, Buenos Aires, Espasa-Calpe, I940; 3." ed., I943. 


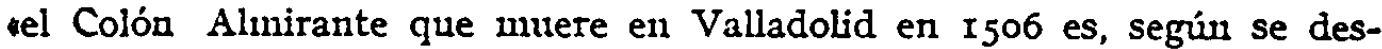
prende de algunas de sus disposiciones testamentarias, el mismo Colombo, lanero de Génova [-su lengua materna era el dialecto genovés 1-], que figura en los documentos de r 470 a 79, según probó el académico Angel Altolaguirre, y confirmó liasta la saciedad el profesor Giovanni Monlconev (ibid., p. 9).

Èn efecto, contra la hipótesis de Colón español está el hecho de que el español que hablaba - a juicio también de quienes lo oyeron-. "revelaba no ser lengua materna del navegante" (ibid., p. II), y contra la hipótesis más especifica de Colón gallego, está el hecho de que «los dialectismos del occidente de la Península que muestra el habla del almirante no son gallegos, sino decididamente portugueses", por más que el portugués no es tampoco lengua materna de Colón (ibid., p. I3), sino lengua aprendida en su época juvenil en Lisboa o en otras tierras portuguesas (ibid., p. I6), donde se casa con Felipa Moniz y donde "por $\mathrm{I}_{484-85}$ hace proposiciones de descubrimiento al Rey Juan II de Portugal" (ibid.), las (jue, por ser desatendiclas, lo llevan finalmente a España a fines de 1485 . (Así pues, la falta de visión de Juan II es la razón de que en este momento los hispanoamericanos no estemos hablando portugués). Se ve con claridad que este estudio sobre la lengua de Colón es un buen ejemplo de la colaboración que la lingüística puede ofrecer para dilucidar un problema de historia personal, aunque de repercusión universal.

I.I.5.2. La le ng a de $\mathrm{S}$ an $\mathrm{ta} \mathrm{T}$ e $\mathrm{r}$ e s a ya había sido objeto de consideración por parte de don Ramón en el ensayo de conjunto que le dedicó en 1933 al lenguaje del siglo XVI ${ }^{2}$, pero sólo incidentalmente, de modo que en el nuevo estudio que le dedica en I94I lo desarrolla en algunos puntos "sin la limitación de entonces" (Colón, p. I29). Sin embargo, las conclusiones son las mismas: I) simplicidad y llaneza rayanas en el ascetismo, que la llevan a decir anque por 'aunque', cuantimás por 'cuanto más', ipróquita por 'hipócrita', traurdinario por 'extraordinario', etcétera, no por ignorancia de las formas correctas, sino por un acto de humildad, por "un trabajo de mortificación ascética» (ibid., p. I34); 2) una espontaneidad en todo concordante con su incontrolable

1 La lengua de Cristóbal Colón, el estilo de Santa Teresa y otros estudios sobre el siglo XVI. Col. Austral, Buenos Aires, Espasa-Calpe, 1942, p. 26 (cit.: Colón).

2 El lenguaje del siglo $X V I$, en Cruz y raya, I933, VI, pp. 9-63; reimpreso «con algunas supresiones y bastantes enuiendas", en Colón, pp. 5I-90; también en Mis páginas preferidas. Estudios lingüisticos e históricos, Madrid, Gredos, I957, y además en España, II, pp. 127-159. 
tendencia a la improvisación, y 3) un gran poder imaginativo y creador.

I.I.5.3. La le ng u a de $\mathrm{I}$ o pe se entiende mejor si se empieza por distinguir en su obra dos clases:

-Una - oinspirada en icleales ncoplatónicos» y dirigida eal público universal, al público cuyar mezclada diferencia de entendinientos hay que satisfacer y educar a la vezi - la que por esencia se puede llamar poe si a in t u ral, la de los metros cortos, romances, letrillas, villancicos, glosas, además de la prosa semejante a la de las novelas; y otra un público restringido, eclucado en el preceptisnno neoaristotélico del renacimiento-, la po es $\mathrm{i}$ a d o c t a , la de los sonetos, rimas, canciones, églogas, poemas y demás producciones en metros italianos, junto con la prosa semejante a la de La Arcadian (España, II, p. 336).

Ahora bien,

*en [su] lenguaje, como elemento primordial de la expresión estética, impera el criterio que antepone el gusto, aun contra lo justo, tanto en el arte natural como en el clocto. Issto se ve muy particularmente en la construcción die la frase, donkle se observa una que podrlamos llamar sintaxis de *a buen entendedor", confiando siempre en que una vez indicado to esencial, los rasgos salientes que deben impresionar el ánimo, queda satisfecho el gusto, y es pesaclez el entretenerse en el desarrollo racional, lógico, completo y justo de la idea; la frase sugeridora vale más que la expresión acabada: *a buen entendedor, pocas palabras" (ibid., p. 338).

Es decir, que urealiza plenamente el principio declarado por Valdés: e s c rib o c o mo h a b lo" (ibid., pp. 338-9). Pero si esto es válido de un modo general, se advierte, con todo, que mientras en la poesía natural predomina la llaneza -y Lope, en el diálogo teatral imitado del cotidiano, "trae a la literatura todo el habla conversacional", con sus lugares conuunes e incluso

con todos sus elementos auxiliares, lo misuro que si fuese realmente hablada, no escrita, encomendando a la entonación y al gesto parte de la significacions (ibid., p. 339)-,

en los poemas doctos abundan los tecnicismos y latinismos.

- Estos poemas [.... introducen por primera vez en la poesia multitud de voces tomadas a la arquitectura (plinto, arquitrave, sinedras, tresdoses...), a la pintura (bosquejo, ancorgue, genoli, 4esbelleza, voz que la pintura trajo de Italian, alo que los pintores llaman encarnación...), voces propias de la astronomia (ecliptica, hiadas, helices, 'la osa mayor', sextiles, equinoccial, coluros...), de la medicina (febricitante, intercadente...), de la zoologia exótica 
(cercopileco, psitaco...), de la náutica, de la nuilicia, en fin, de todas las disciplinas profanas y sagradas. En el libro 5 de La Arcadia, I598, hay un breviario de las artes liberales; en los Triunfos Divinos, 1625, se intenta una verdadera enciclopedia del catolicismon (ibid., p. 340).

Tal erudición no es un caso aislado en la literatura de la época, sino un rasgo característico de la cultura europea de entonces, que use apoya en el concepto de la poesia $\mathrm{como}$ c i e n cia, muy válido ya en el siglo XV) (ibid., p. 34I), y del cual Lope está plenamente consciente; segúu sus palabras,

mo sólo ha de saber el poeta todas las ciencias, o al menos principios de todas, pero ha de tener grandísima experiencia de las cosas que en tierra - mar suceden..., porque ninguna hay en el mundo tan alta o intima de que no se le ofrezca tratar alguna vez, desde el mismo Criador hasta el más vil gusano y monstruo de la Tierra" (ibid.).

En cuanto a su «lenguaje latinoso», Jáuregui,

\#burlaindose de lo liso, llano, claro y puro de que sicmpre presumia Lope, saca a la vergüenza, soblo en La Jerusalen, hasta 150 voces ininteligibles. Pero cuando vemos - apunta muy atinadamente don Ramón- que entre ellas están muchas hoy corrientes: horóscopo, tulipán, sistema, increpar, ileso, truculento $y$, aunque con acento diverso del actual, antropofago, sarcófago, apócrifo, esqueleto, vislumbramos la deuda grande que el léxico moderno tiene con el trabajo de enriquecimiento de la ciencia poética que Lope se propuson (ibid., pp. 343-44).

Por lo demás ¿qué son I50 latinismos en más de 25.000 versos que tiene La Jerusalén?:

"Son nada comparados a los innúmeros cuidados que Lope dedica a embellecer el habla natural, lisa y llana; tan natural que Jáuregui mismo le censura muchos versos por excesivamente llanos" (ibid., p. 344).

Ess cierto que Lope "se dejó también teñir algo por el cultismo" (ibid., página 350) del Polifemo y Las Soledales; pero todo no pasó de ser más que un corto embrujo del canto de sirena del estilo gongorino que hacía «metáforas de metáforas» y se perdía «en continuas transposiciones o hipérbatos» (ibid., p. 349). Nada sincero en el fondo, pues él mismo confiesa y lamenta haber escrito (el mismo año 1627 de la muerte de Góngora) su Corona trágica «a sangre fría» (ibid., p. 352).

"Queda asi Lope de Vega como el gran poeta natural que vive en una época de transición hacia la innaturalidad. En el desenvolvinuiento del idioma actúa siempre como continuador de la magnifica tradición de lla- 
neza imperante en el siglo Xvr; sirve como barrera firme de esa llaneza contra la fuerza innovadora del culteranismo; y en tan critica época perdura históricamente como el más grande artifice en la perfección y enriquecimiento del idioma" (ibid., p. 353).

La lingüistica y la literatura han confluido aquí mostrándomos cuán fntinamente ligadas estaban en una mente tan bien orgauizada como la de Meuéndez Iidal. No en vano, cuando aún preparaba su doctorado (I890-9I). upensaba aspirar a una cátedra de Literatura que decían podría tardar poco en salir a oposiciónn (Conde, $M . P ., \mathrm{p} .3 \mathrm{I}$ ). Y no en vano tampoco nos confiesa que

1o juportante para mi formación cientifica es que propendi a considerar inseparables la historia de la lingülstica con la historia literaria (crónicas, métrica, poesia épica), y con la historia politica y social (personajes, instituciones, sucesos)" (ibid., p. 35).

I.I.6. La competencia 1 exi cog ráfic’a de don Ramón queda afianzada de una vez para siempre en el excelente "Vocabularion que como parte tercera completa su monumental Cantar de Mio Cid '.

I.I.6.I. Dicho "Vocabulario", que en la edición de I954 constituye un volumen de casi 500 páginas, es un estudio gramatical, semántico y etimológico de todas las voces aparecidas en el Cantar, con indicación de todas sus variantes, del o de los versos en que aparecen, y en las voces de difícil comprensión, de citas extensas de otros textos medievales, por lo que viene a ser en verdad un diccionario etimológico del español escrito de la Edad Media.

I.I.6.2. Si a esto se agrega que en el aspecto gramatical se remite en forma constante y circunstanciada a la "Gramática" (en el primer yolumen del Cantar ${ }^{2}$ ), y a gramáticos de la talla de Bello y Cuervo; que en lo semántico, adeinás de las diversas acepciones del término, se indican los sinónimos usados en el mismo poema, y que en lo etimológico se alude a las obras de romanistas de la calidad de Díez, Körting, MeyerLüble, Gastón Paris, aunque a veces para rectificarlos, se podría decir que el "Vocabulario» es un modelo de técnica lexicográfica.

I.I.6.3. Pero su valor no termina aquí: el estudio -que «aspira [...] a comprender un comentario arqueológico del Cantarn (ibid., p. $x$ ) (por el camino de explicar las antigüedades, costumbres, instituciones, etcétera" (Conde, M. P., p. 35) - entre glosas y escolios (algunos de lasta 24 pp., como el dedicado a Carrión), da una visión acabadísima

1 V. infra, I. 3. 4. 2.

2 T. III, 1954, vol. I, (cit.: Cantar, I). 
del mundo natural y cultural en que le tocó vivir a Rodrigo Diaz de Vivar, el Cid Campeador. ¿Quién podría decir que esta obra no empezó a gestarse en don Ramón siendo niño, cuando, al encontrar la Biblia de Scío, se sintió atraído (irresistiblemente por su curioso vocabulario medievaln? (ibid., p. IG).

I.I.7. Iiste precedente que es el "Vocabulario", resulta muy útil para comprender la autoridad intelectual de Menéndez Pidal para sentar las bases teóricas de lo que debe ser un diccionario ideal. $Y$ esto es justamente lo que ha hecho en El diccionario que deseamos, magistral ensayo 1 exicológico que aparece a manera de prólogo en el Vox. Diccionario general ilhustrado de la lengua española, a cargo de S. Gili Gaya ${ }^{1 .}$

I.I.7.I. Puede asegurarse que todos los aspectos fundamentales de un diccionario perfecto han sido considerados.

r.I.7.I.I. En cuanto al monto de material léxico: I) la decisión previa de si se tratarí de un diccionario selectivo de la le ng u a escrit a, normalmente la de los escritores tenidos como mejores, o de un diccionario exhaustivo de la 1 e $\mathrm{ng}$ u a ha b la $\mathrm{d}$ a,

"menos ambicioso de pureza normativa, más afanado en el acopio de todos los biencs, sean ricos, sean de escaso valor" (Dicc., p. xrv);

es decir, de un diccionario en el que

"todo lo que literariamente se escribe, como no sea una aberración puramente individual y extravagante, todo lo que se habla por una agrupación de la sociedad no totalmente inculta, debiera ser recogido, ora proceda del momento actual, ora venga de tiempos pasados" (ibid.);

la dificultad práctica de esta última empresa recomienda, a su juicio, contentarnos con un diccionario selectivo; 2) el respeto no sólo a las voces de uso cotidiano, sino también a los arcaísmos - remanentes del pasado- y a los neologismos - que inician su vida sin prognosis segura de su destino; 3) la consideración no sólo de términos de la lengua común, sino también de las lenguas especiales, o tecnicismos, precisamente por el extraordinario desarrollo actual de la técnica y de los medios de difusión masiva, que hacen que el profano a cada rato entre en contacto con dichas expresiones; 4) la inclusión, en el diccionario total, el «dic-

1 Barcelona, Spes, I945 ( Prólogon); 2.2 ed., I953 ("Il diccionario que deseamosw); reimpresión, 1964 (cit.: Dicc.); reprod. en Estudios de lingïística (v. supra p. 236, n. 5.), como "El diccionario ideal", pp. 93-I47. 
cionario archivo", de barbarismos, solecismos y extranjerismos, "calificando la voz en cada caso" y nuxtaponiéndole las voces sustitutivas preferibles";

-[se] ha de recoger - pues- en gran abundancia tocla clase de defectos, para su corrección, y por último hasta [se] ha de tener en cuenta que hay escuelas defensoras, en teoria, del solecismo y del barbarisuo (Baudelaire, Verlaine, Unaumu, Valle-Inclán). (ibid., p. xviii).

Esta última recomendación, por lo demás, es totalmente consecuente con la crítica que hace a

"comentaristas coivo Clemencin y Hartzenbusch, al corregir muchas frases del Quijote, $o$ [al] purista moderno que se llena la boca poniendo a Cervantes entre los escritores incorrectos [...]. porque no llegan a tener el menor atisbo de que la expresión irreflexiva e irracional tiene su sintaxis tan propia y legítina como la expresión lógica, porque las ocurrencias del gusto pucden solvreponerse a las razonables normas de lo juston (España, II, p. 339).

¿No recuerda esto aquello de que muchas veces el corazón tiene razones que la razón no comprende? Hermoso gesto, éste de don Ramón, en favor de la función expresiva del lenguaje.

I.I.7.I.2. En cuanto al modo de presentar el caudal léxico,

[se] tiene que extremar el cuidado en exponer todo ese material bajo principios históricos, gramaticales y estilisticos guiadores del uson (Dicc., página xix).

En consecueucia, I) se han de señalar la etimología de la palabra y la fecha en que aparece en el idioma, upuntos de partida para la ordenación de las varias acepciones" (ibid., p. $\mathrm{xx}$ ); es decir, que el sistema de ordenación ha de ser el histórico, el cual unos da la lógica de la vida, la de la realidad lingüistica, muy diversa a veces de la lógica que razona en abstracto" (ibid.); 2) se ha de completar la definición con la indicación de voces sinónimas y afines;

[3] upara instruir al hablante sobre el empleo de uma palabra de uso no general, el léxico debe esurerarse en declarar dónde esa voz. es usada, esto es, a qué área geogrífica se exticude su comprensibilidad" (ibid., p. xxi);

4) se ha de tender más bien a la abundancia que no a la escasez en toda clase de observaciones gramaticales (ibid., p. xxiii); 5) se ha de in- 
dicar en cada voz la estimación afectiva en que se la tiene: familiar, vulgar, respetuosa, solemne, despectiva, humorística, burlesca, eufemística, etc.;

"cl que habla, el que escucha, según la palabra sea una u otra, proyecta sobre una misma representación objetiva una luz afectiva diferente, que ora vulgariza o rebaja el concepto, ora lo ennoblece e idealiza [...], según la tensión de ánimo en que se halla el hablante, según la persona o el público a quien él se dirige, según el cfrculo social en que la representación surge, (ibid., p. xxiv);

6) se ha de decir si su uso es rural o urbano.

r.I.7.2. En suma, don Ramón revela, en su concepción de un diccionario ideal, una actitud declaradamente historicista; en la concepción del lenguaje -en consecuencia-, una visión dinámica del mismo:

"el diccionario - dice- ha de considerar la vida de las palabras coino un continuo flujo y reflujo, perpetuo devenir en los actos sucesivos en que cl lenguaje se realiza. (ibid., p. xxviii);

lo que no le impide, sin embargo, pensar en la posibilidad de fijar el idioma: «así -agrega más adelante- [el diccionario] cooperará a la fundamental fijeza del idioman (ibid.); pero es que se trata del idioma en cuanto "sistema", y no en cuanto "norma", pues a tal fijeza puede contribuirse

uno con un simple fallo autoritario, sino dando conocimiento de la evolución histórica del lenguaje, para que el lector pueda continuarla en nuevas creaciones lingüisticas, con juicio documentado, con elección ilustrada" (ibid.).

¿Y en cuanto a los criterios de corrección manejados por Menéndez Pidal? Bueno, don Ramón ha sido en realidad muy claro al distinguir entre diccionario selectivo, para el que las voces se han de elegir "atendiendo sólo a lo que es propio de la parte más culta de la sociedad hablante" (ibid., p. xiii), y el diccionario tota 1 , o diccionario archivo, o diccionario exhaustivo, para el que todo el repertorio léxico de una lengua debe tenerse en cuenta, pues,

nes preciso -nos dice- que los diccionarios pierdan algo del esquematismo rígido en que hoy han venido a encerrarse $y$ procuren reflejar cuanto mejor puedan la vida del idioma (ibid., p. xxrii);

han de tener en cuenta que "voces hoy, no sólo bajas, sino torpes, eran literarias y nobles para Berceo y para el Marqués de Santillana» (ibid., 
página xxviii). La norma lingüística no es algo que se establezca, $\checkmark$ pues, de una vez para siempre, por lo que

whan de mirar lo que hoy son defectos, no como absolutamente tales* (ibid.); como el lenguaje cambia con el continuo evolucionar la vida de un pueblo, el léxico, aún el más aferrado a la autoridad de los escritores y del buen uso del pasado, tiene que recibir mucho del lenguaje actual de los negocios y del trato diario de las gentes" (ibid., p. xiii);

así, el diccionario total uno será un panteón consagrado al culto del bien decir, sino guía en una etapa del inacabable camino que va recorriendo el lenguaje" (ibid., p. xxviii). Por todo esto, y a pesar de que en el estudio que comentamos diga que

unas palabras dan a la euunciación del concepto un t o no b a jo, d e Infi ma $v$ ulgaridad, [y que] el caso más patente es el de aquellos conceptos asquerosos o repugnautes que el lenguaje urbano no tolera sino atenuadamenten,

o que

"las clases educadas emplean una designación metafórica o bien otra palabra de significado recto, pero menos usada del vulgo, de modo que no está cont a m in a d a con las representaciones más b a jas que el uso incivil adhiere a sus vocablos (ibid., p. xxiv; el destacado es mio);

a pesar de todo esto, digo, que más que un purismo lingüístico, como pudiera pensarse, revela un purismo mental, creo que don Ramón habria suscrito cabalmente este "modernísimo" juicio de hace 345 años emitido por Gonzalo Correas en su Arte de la lengua castellana ${ }^{1}$ :

"Ase de advertir que una lengua tiene algunas diferenzias, fuera de dialectos particulares de provinzias, conforme á las edades, calidades, i estados de sus naturales, de rrusticos, de vulgo, de ziudad, de la xente mas granada, i de la corte, del istoriador, del anziano, i predicador, $i$ aum de la menor edad, de muxeres, $i$ varones: $i$ que todas estas abraza la lengua universal debaxo de su propiedad, niervo i frase: i á ca da uno le está bien s u l e $\mathbf{g}$ u axe, i al cortesano no le está mal escoxer lo que pareze mexor a su propósito como en el traxe: mas no por eso se á de entender que su estilo particular es toda la lengua entera, i xeneral, sino una parte, porque muchas cosas que él desecha, son uuui buenas i elegantes para el istoriador, auziano, i predicador, i los otros: (ed. de 1954, p. I44; el destacado es wio).

1 Ms., Salamanca, 1625; publicado en Madrid (sobre una copia), incounpleto, edicióu del CoNDE DE LA VizAÑa, I903; ed. de EMitio Alarcos Garcia (sobre el original), Madrid, RFE, anejo LVI, I954. 
Es decir, que, a la idea errónea bastante generalizada de la existencia en español de una sola norma lingüística aceptable como correcta, hay que oponer la idea indiscutible de la existencia de muchas normas, por la variedad de circunstancias que rigen el uso de una lengua mediante la cual los hablantes tienen que realizar un proceso constante de adaptación a ellas. Fenómeno éste de todos los tiempos, como lo pone de manifiesto el mismo Menéndez Pidal en sus Origenes del español:

- In la desconcertante variedad de formas que ofrecen nuestros documentos no hemos de ver un revoltijo del azar, sino wn sordo combate de tendencias (p. 526); el lector se aturde al pasar la vista por tantas formas dispares de un mismo vocablo: altariu, antario, autairo, autero, auterio, outeiro, octeiro, oteiro, otero y muchas más por el estilon (ibid., p. 515);

conıo si faltara una norma rectora de la lengua vulgar antigua; sin embargo,

"Ho es la falta le una norma lingüistica como a primera vista parece, sino la convivencia de muchas nommas que luchan entre si con muy equiparadas fuerzas. El que habla sigue consciente o subsconscientemente ora una, ora otra, de esas normas en lucha; prefiere una u otra, según el tono y la ocasión del cliscurso, según las influencias pasajeras que se entrecruzan en la mente mientras se produce el acto lingüísticon (ibid., p. 526).

La lección es, entonces, la existencia real, en todos los tiempos, de una pluralidad de normas, y el hecho de que todas son correctas - si se emplean con oportunidad-, pues todas satisfacen alguna necesidad expresiva del hablante. Magnifica lección de sabiduria lingüística - tan necesaria a más de un especialista en cuestiones de lenguaje - adquirida a través del conocimiento profundo de la historia de nuestra lengua. Véase, por ejemplo, lo que nos dice también del, siglo XVI, siglo decisivo para el destino del español y clave para dilucidar muchos problemas del español de América:

4I) En la época de Nebrija se intenta la primera solución al problema lingǘstico de España, con una orienta ción a nd a l u za. Se forma el tipo social del cortesano y la lengua de la cortesania hispano-italiana, uajo los aupicios del "buen gusto".

2) En el periodo de [el toledano] Garcilaso de la Vega esa lengua cortesana se impone en la literatura, regida por una no r m a to le d a na, que repele a la andaluza. Auge del italianismo. Se desechan los últimos restos de afectación del periodo nebrisense.

3) In la época de los grandes misticos [Luis de Granada, Santa Teresa, Luis de I,cón, Juan de La Cruz] se rechaza el tipo de lenguaje cortesano para imponer un tipo $\mathrm{n}$ a $\mathrm{c}$ i o $\mathrm{n}$ al, pero predominando modalidades de Castilla la Vieja [...]. 
4) Ion el periodo de Cervantes empieza a perderse la fe en lo natural y a afirmarse el valor estilistico de la afectación. Se olvida toda norma local del lenguaje para stustituirla por una norma literaria de grandes individuaciones estilisticas» 1 ,

criterio, este último - agreguemos nosotros- que conforma, en el siglo Xvin, la mente de los reales académicos españoles de la lengua, según se manifiesta en su "Diccionario» y en su "Gramática», y que sigue vigente todavía en la mayoría de los académicos del Viejo y Nuevo Mundo hispánicos.

I.I.S. Lo que llevamos dicho hasta aquí ya nos hace evidente el cariño entrañable que Menéndez Pidal tenía por la $\mathrm{H}$ is tori a. Me atrevo a asegurar que no hubo un solo aspecto de la lengua $-y$ de cualquiera otra institución humana - que él considerara, que no lo hiciera bajo la invocación de Clío, la musa coronada de laurel, encargada de velar por la sabiduria trasmitida por las edades, hasta el punto que pudo haber dicho con $\mathrm{H}$. Paul que el único estudio cientifico del lenguaje es el que se emprende con el método histórico ${ }^{2}$.

Su vocación por la Historia forma parte de su historia vital. Allí estaba entretejida con su niñez, mostrándole la larga línea fáctica del pasado cuando don Ramón era apenas un pequeño presente: "Entre los libros que, rondando por la casa, se encontraba nás a mano, contaban los históricos: la Biblia [...], la Historia Sagrada del padre García del Mazo, la Historia del padre Mariana, la Historia Universal de César Cantú (Conde, $M . P$. . p. 25). Pero será el mundo medieval con todo lo que tiene de romántico efluvio el que finalmente lo cautivará por completo hasta hacer de él el inmenso medievalista que fue. Es comprensible entonces que "la tristeza claustral de los viejos patios monacales invadidos por la yedra, los muros cólumes y tapizados por el moho, [despertaran] su gran emoción ante el pasado vivo en la piedra, en los códices, en las crónicas, en los grabados, en la huella del hombre, en la rerdad impávida y secular con que a veces nos habla el silencio de un claustro" (ibid., pp. 252-3).

1 Colón, p. 9o. Recuérdese que el andaluz Antonio de Nebrija escribió en I 492 - mientras estaba por descubrirse América- la primera gramática de la lengua castellann, $y$, entre otras razones, segiu nos cuenta, porque «despues que Vuestra Alteza [ - la Reina Isabel, a quien la obra iba declicada-] wetiesse debaxo de su ingo muchos pueblos bárbaros i naciouales de peregriuas lenguas [...], conel vencimiento aquellos teruian necessidad de recebir las lejes quel vencedor pone al vencido i con ellas nuestra lengua..." (ANTONIO DE NEBRIJA, Gramática castcllana, ed. de GaIINDU y ORTIz, Mladrid, I946, vol. I, p. I I).

- Grorgis MIUUNix, Historia de la lingiiistica diesde los origenes al siglo $X X$. Mradrid, Gredos, IoGs, 1). 218. 
Hasta su interés por el Derecho -y la Historia del Derecho, por supuesto-, "la más fundamental y característica de las donaciones medievales" ${ }^{1}$, se entiende así mejor.

Y así también cobra todo su sentido esta confesión suya: "He seguido sin vacilar la dirección emprendida [desde la redacción primitiva del Cantar de Mio Cid en IS93], dependiendo todos mis trabajos del hilo central de la poesía épica y el lenguaje medieval" (Conde, $M$. $P$., página 229). Sin vacilar, durante un siglo, este hombre que thabia hecho un pacto con el tiempon (ibid., p. 237) para estudiar y hacer Historia. Sin vacilar, acicateado desde niño por una frase que de su lectura infantil de la Biblia - nos confiesa - «siempre quedó flotando sobre mi espíritu: maldito el que una vez puesta la mano en el arado vuelve la cabeza atrás" (Conde, M. P., p. 229).

Según Dámaso Alonso, "Menéndez Pidal había llegado al estudio de la lingüística acuciado, sin duda, por una necesidad, sentida al meterse en los pormenores de su trabajo. El estudio de las leyendas y los poemas épicos, así como el de las crónicas, le llevó al convencimiento de que no era posible hacer ninguna labor seria en ese terreno, sin un intenso cultivo de la historia de la lengua" ${ }^{2}$. No sé si esta presunción se ajusta enteramente o no a lo que cuenta el propio don Ramón: "A los veintitrés años mi entrada en el campo de las letras tomó dirección lingüistica, porque respondía al propósito de acudir a un concurso abierto por la Real Academia Española sobre la Gramática y el Vocabulario del Poema del Cid" (Conde, $M . P^{2}$., p. 6r). Pero lo seguro es que llegó a la historia de la lengua desde la historia de la literatura, que cultivaba durante su doctorado, sin salirse jamás de la Historia. Abonan esta opinión el hecho de que la primera publicación de don Ramón, cuaudo sólo tenía 22 años de edad, fuera La peregrinación de un cuento (I89r), y la jrimera obra importante de su rica bibliografía, el Cantar de Mio Cid (cuya primera versión es de r893; ver I.3.4.2.), verdadero hilo de Ariadna de todos los trabajos posteriores de don Ramón (Conde M. P., p. 229), como La leyenda de los Infantes de Lara (I896) ${ }^{3}$, y a dos años de ésta, como "mera consecuencia no más de [este] libro" (ibid., 1. 43), las Crónicas Generules de España. Catálogo de la Real Biblioleca. Manuscritos ( $\mathrm{I} S 98)$, bajo cuyo modesto título "ocúltase

I C. G. Crume y Is. I'. JaCon, ed., I:l legado de la edad Media, Madrid, I'egaso, I944, p. xiv.

Insula, 1959. Año XIII, núm. 157, P. I.

"Madrid, I 896; reimpresa en "Obras de R. Mencindez l'idal", Vol. I. Madrid, Centro de Iistulios Históricos, I93. (cit.: Leyenda).

- Madrid, sucesores de Rivadeneyra, I 898. 
nada menos que el primer estudio formal acerca de la historiografía española» ${ }^{1}$.

I.I.S.I. Siglo a siglo, don Ramón fue perfilando la historia del español (pensando, sin duda, dar a luz alguna vez su Historia de la lengua española, que, por desgracia para nuestra ciencia, nunca apareció): desde los comienzos de nuestra lengua hasta el siglo XI, en Origenes del español (v. supra p. 226, n. 8); durante la Edad Media, en su conjunto, en "Advertencia sobre la lengua medieval", incluida en su Antologia de prosistas espainoles 2 (sobre todo, y en las innumerables notas de esta antología en las páginas pertinentes); durante el siglo xv, en La Lengua en tiempo de los Reyes Católicos (del Retoricismo al Humanisıno) 3; durante el siglo xvi, en el ya citado ensayo El lenguaje del siglo XVI 4, umuestra de un antiguo proyecto de historia breve de la Lengua españolan (Conde, M. P., p. 38); durante el siglo XVIr, en Gran innovación en el habla comin del siglo $X V I I{ }^{6}$; trabajo que se complementa con Culteranos y Conceplistas "; durante el siglo xvin, en la misma Antología, a propósito de Jovellanos, y en una visión de conjunto, desde sus origenes hasta nuestros días, en su Mannal de gramática histórica española (v. supra p. 234, n. I).

I.r.8.2. Pero, sin lugar a la menor duda, la obra cumbre en este sentido y sin parangón en las lenguas modernas, es la primera: Origenes del español - con razón la que don Ramón más queria- (Conde $M$. $P$. p. I37), anpliamente comentaba y elogiada por todos los grandes de la lingüística y la filología románicas: Américo Castro, Amado Alonso, Aurelio M. Espinosa, H. Keniston, C. C. Marden, A. Meillet, E. Bataillon, A. Martinet, W. von Wartburg, Leo Spitzer, G. Rohlfs, H. Meier y tantos otros.

I.I.S.2.I. ¿En qué reside su importancia? En muchas cosas. Para Rohlfs representa «los primeros intentos serios de determinar, a base de realidades fonéticas y léxicas, la articulación dialectal de la Península entera" (Rohlfs, Mamual, p. I75), lo que ha hecho decir tambien a Vidos que es una obra uindispensable [...] para el estudio del origen de las lenguas iberorrománicas y de la situación lingüística de la Península

1 M. MLNíndez \& Prisyo, Discrursos ante la Real Acad. Española, I902; reimpreso en Estudios y' discursos de crttica lileraria, I, I94I.

2 V. supra p. $240,11.5$.

3 Cuadernos Hispanoamericanos, 195I, XIII, pp. 9-24.

- V. supra p. 2fl, 11. 2.

- Rev. Iuérida, Rio de Janeiro, I, abril, r959.

- España, II, 1p). 50I-5.77. 
Ibérica hasta el siglo XI' ${ }^{1}$. Von Wartburg ${ }^{2}$, por su parte, estima que es importante además "für die Geschichte der andern romanischen Sprachen"; y, por si esto fuera poco, "auch die allgemeine Sprachwissenschaft wird, besonders im Schlusskapitel, manchen Gedanken finden, der ihr neue Ausblicke erïffnet».

r.r.8.2.2. Y en otra parte, Rohlfs estima que "un valor especial de esta obra consiste en reconstruirnos la prehistoria del español en los siglos IX-XI, trabajando sobre fuentes desatendidas hasta entonces (glosas, documentos latinos [notariales], formas topónimas antiguas, mozárabe)". (Rohlifs, Mannual, p. I33).

Sobre la inportancia cle tales documentos para la historia de nuestra lengua, escuchemos al propio Menéndez Pidal:

"Cuando [en rgr5! fui a trabajar en los archivos cclesiásticos de Ireón, intenté el estudio [...] empezando por los documentos del siglo Ix y siguiendo por entre el rico tesoro de los que se conservan del siglo $x ;$ y en ellos encontré una inesperada cantidad cle formas romances que hacia fines del siglo XI cmpezaba a decrecer también, para agotarse en esa baja latinidad que en los dos primeros tercios del siglo xir nos habia repelido antes.

Descubria así dos encontradas corrientes de vulgaridad [esto es, de carácter romance] en la lengua notarial: una que venia de los siglos antiguos [que karranca del latin vulgar de los primeros siglos medievales*] y se extinguia en el curso de los dos primeros tercios del xI [por ala reforma cluniacense que restauró la latinidadu]; otra que empezaba en el último tercio del xir y triunfaba con la adopción del lenguaje vulgar en el xnir [por un movimiento general a toda la Romania que llevaba a seculizar la cultura, y por lo tanto a entronizar el romance como lengua oficial ordinaria, dejando el latin solamente como supletorio para los actos más solemnes") (Origenes, p. viii). "He aqui el capital interés de esos documentos de los siglos $\mathrm{x}$ y xr; ellos nos abastecen de formas jamás escritas antes en los textos del periodo literario por remotos que fuesen; la extraña catadura de alguna de ellas no habia jamás aparecido ante los ojos del filólogo moderno; hasta su viejisima ortografia era o ignorada o arcana" (ibid., p. ix).

"La época prinitiva del idioma era ya teóricamente conocida por la filologia, mediante la comparación del latín con el romance moderno, de donde se deducen las formas remotas del romance naciente. De esta época primitiva, cuyas formas lingüisticas se conocen casi sólo teórica o deductivamente, habia que saltar a la época literaria, conocida ya en manuscritos auténticos desde poco antes de I200. Ahora, la historia documental del idioma ganará muy curiosos aspectos al ser prolongada tres siglos más atrós, al llenar con hechos y fenómenos desconocidos una época que antes

1 I3. E. VIdos, Manual de lingiiistica romdnica. Madrid, Aguilar, 1963, p. 344.

$2 Z R P h, 1928, \mathrm{XLVIII}, \mathrm{pp} .457-46 \mathrm{r}$. 
Labia que pasar por alto, entre la época prinitiva y literaria. Esta época intermedia [preliteraria], de la que antes nada se decla, nos podrá ahora revelar más de un secreto, más de un episodio significativo de la evolución primera del romance (ibid.).

I.I.8.2.3. La obra es también particularmente valiosa por la uexcelente caracterización de la cultura y de los dialectos mozárabes) (Rohlfs, Manual, p. 98), a los que don Ramón tuvo acceso muy bien auxiliado por el conocimiento del árabe ${ }^{1}$. La España mozárabe, esto es, la España cristiana bajo la dominación árabe a raíz de la arrolladora invasión que sobrevino en $7 \mathrm{II}$, es estudiada en 25 enjundiosas páginas (en la ed. de I956), dándose uuna [cabal] idea de los centros culturales, o sea centros de vida política, social y literaria, que podian ser focos de irradiación para el uso lingüístico" (Origenes., p. 4I5). Si se tiene ell cuenta que ulos principales centros de vida romano-goda, Toledo, Hispalis [hoy Sevilla], Córdoba, Mérida, Tarraco [hoy Tarragona], Cesaraugusta [hoy Zaragoza], permanecieron cuatro o más siglos teniendo por lengua de culturia d árabe y muy aislados respecto a los cristianos del norte» (ibid.), se comprenderá la importancia de la obra que nos ocupa para darnos cuenta de la tremenda vitalidad que debió tener la lengua romance, si pudo sobrevivir a la presión arábiga, pues Menéndez Pidal da como un hecho que ulos mozárabes hubieron de couservar siempre su lengua románica" (ibid., p. 4I6).

I.I.8.2.4. Según Américo Castro, Origenes del español es «de capital importancia para el método histórico» ${ }^{2}$, pensando, sin duda, de un modo particular, en el método geográfico-cronológico inventado por Menéndez Pidal y convenientemente aplicado aquí: «Nous savious que les méthodes de la grammaire historique traditionelle étaient insuffisantes [...]" nos dice Castro. "La géographie linguistique, sur ce point, a beaucoup élargi nos idées. Mais cette géographie linguistique néglige le concept de temps. En combinant la notion de temps avec celle d'espace, M. P. a fait faire un grand pas à notre science» ${ }^{3}$. Del mismo parecer es Coseriu cuando afirma que pueden verse en esta obra iverdaderos modelos de una sabia aplicación del método geográfico a la historia lingüístican 4.

1 ....] mi mayor gratitud -nos declara- es para el catedrático de árabe, Codera, que [durante los años de la licenciatura (1885-90)] nos hacia interesante el estudio de la munismática unusulmana y el de las dinastías aragonesas de los Tochibies y de los Benvihud, (CONDE, M..P., p. 28).

2 En W. MIEYTR-LüBkE, Introducción a la lingiïtstica románica. Madrid, RFE, Anejo I, I926, p. 50, nota $I$.

3 Romania, 1928, I,IV, pp. 125-130.

- 1:. Coseriv, La geografia lingüistica, en Rev. de la Fac. de Hdes. y Ciencias, Montevideo, Unir. de la República, I955, núm. If, pp. 29-30, nota 1. 
I.I.8.2.5. En opinión de Ortega y Gasset, «lo que más vale en la obra [...] no es la infatigable exploración ni el cúmulo de saberes. Si no hubiere en ella más que esto no mereceria, con la pureza que lo reclania, el divino título de ciencia. Ciencia no es erudición, sino teoría. La laboriosidad de un erudito empieza a ser ciencia cuando moviliza los hechos y los saberes hacia una teoría. Para esto es menester un gran talento combinatorio compuesto en dosis compensadas de rigor y de audacia. [Y] este es, a [su] juicio, el don ejemplar de nuestro Pidal " ".

I.I.8.3. Un año después de haber aparecido los Origenes, don Ramón publicó un resumen con el título de El idioma español en sus primeros tiempos ${ }^{2}$, resumen que sacrifica integramente el capitulo II del original dedicado a la "Gramática".

\section{I.2. El gramático}

I.2.I. Su labor como gramático está presente en muchas de sus obras; particularmente, y en orden cronológico, en Nolas accrca del bable de Lena (1897) ${ }^{3}$, donde, fuera de una docena de páginas (ed. de Ig62) dedicadas al Vocabulario, las I7 restantes están consagradas a la fonética, morfología y sintaxis del dialecto; en su ya clásico - por su perfección y su consagración- Manual de gramática histórica española (rg04) " "la primera y más clara exposición de las leyes fonéticas y morfológicas del español" ${ }^{5}$, y que aprendí a valorar a través del inolvidable magisterio de Rodolfo Oroz; en El dialecto leonés (I906) ${ }^{6}$, cuyo volumen lo ocupan, casi en su totalidad, la fonética, la morfologia y la sintaxis; luego, en esa obra de trabajo titánico que es el Cantar de Mio Cid (rgos), cuya segunda parte del volumen I $(28+$ pp., en la ed. de

\section{El Sol, 5-XII-I926.}

2 Madrid, edit. Voluntad, r927; otra ed., Col. Austral, Buenos Aires, EspasaCalpe, 1942.

3 V. supra p. 226, n. 4 .

- Publicada primero con el nombre de Manual elemental de granática histórica española. Madrid, Victoriano Suárez, 1904. Desde la $4 .^{\mathrm{a}}$ ed. (I918) dejó de llamarse relementaln, y a partir de la $6 .^{2}$ (I94I) no ha sufrido modificaciones. Es posterior, y muy superior, a la de José Alemany Bolufer (I902) y a la de Salvador Padilla (1903), y anterior a la de Federico Hanssen (rgro; trad. de 1913) y a la de Vicente Garcia de Diego (1914), de las cuales se diferencia por no contener, cono éstas, un capitulo dedicado a la sintaxis. V. supra p. 234, $n$. I.

s S. C[ILI] G[AYA], en Diccionario de literatura española, Madrid, Rev. de Occidente, I949; 2." ed., I953, s. v. Menéudez Pidal, Ramón".

- V. supra p. 226, n. I y 3 . 
I954) se titula justamente "Gramática» "; dedicada igualmente a fonética, morfología y sintaxis, y para lo cual contó, según sus propias palabras, "con la guía de Díez y del tomo primero de la Gramática de Meyer-Lübkc, publicado en I89o, además de monografías de Cornu, Baist y otros" (Conde, M. P., p. 35), y finalmente en los Origcnes del español, donde, como decíamos más arriba, el capítulo II ( 369 pp., en la ed. de I956) se titula también "Gramática", e incluye, junto a temas de fonética, morfología y sintaxis, uno relativo a las grafías y otro sobre los trabajos lexicográficos de los siglos estudiados.

I.2.2. Es evidente que don Ramón, aunque en muchas instancias de su inmensa bibliografía hizo auténtica teoría del lenguaje, no hizo en cambio teoria del metalenguaje que es la Gramática. En este sentido se limitó simplemente - con pocas excepciones- a nanejar, no a definir, una doctrina gramatical tradicional, aunque en muchos puntos divergente de la académica, no obstante pertenecer a la real corporación desde Igo2.

I.2.2.I. Pero llama la atención que ya desde sus Notas de I897 I) considere como gramaticales - aunque sin darles ese calificativosólo tres «partes» y no cuatro, como la Acadenia: fo nét i c a, morfologia y sintaxis; 2) que haya prescindido de la ortog rafi a, como ya lo había hecho Bello; 3) que con total modernidad hable de "fonética", y no de "prosodia", como la Academia, y 4) que con la misma modenidad llame "morfología» a lo que la Academia en su Gramática mayor todavía insiste en darle el anticuado nombre de "analogian, recordando la enconada polémica de los alejandrinos del Siglo III a.C., en torno a las relaciones entre el lenguaje y el pensamiento, y tomando partido en favor de Aristarco de Alejandría. Es que don Ramón, y he aqui otros de sus grandes méritos, hizo siempre gramática científica, y no normativa, atento constantemente a determinar leyes, y no normas, hasta en los casos en que el ojo miope no ve sino «anomalías caprichosas»:

rilos cambios esporádicos] explican muchas excepciones a los principios fonéticos sentados anteriormente [relativos a los cambios regulares], las cuales no deben tomarse como anomalias caprichosas, sino como cambios debidos a otras leyes o principios de menos generalidad o extensión, (Manual, § 64),

incluso cuando en los Origenes incluye un apartado sobre las g a fi as, lo hace como hombre de ciencia, y no como preceptor, pues en dicho

1 MIi propósito - nos dice don Ramón - fue escribir una gramática completa del Cantar de Mio Cid, inventariando en ella lo especial y lo no especial de su lenguaje $y$ comparindolo con el de otros textos" (Cantar, I, p. x). 
apartado se ocupa no en dar reglas para escribir correctamente, sino en describir simplemente los procedimientos empleados en la representación gráfica de los sonidos románicos, proceso especialmente complicado en la representación

"de toda una serie de consonantes palatales ajenas al latín clásico y nacidas [en las leuguas romances] por la activa influencia de la yod, ora latina, ora románica" (Origenes, p. 45).

Es decir, un tema que aún falta en la gramática cientffica de hoy (no obstante tener en cuenta todavia, y muy especialmente, la lengua escrita), y que en los últimos tiempos ha dado origen a una nueva disciplina cientifica: la g r a f e máti c a, y de la cual hay que considerar entonces a Menéndez Pidal como precursor.

I.2.2.I.I. La fon étic a -especificamente la fonética histórica-, "que estudia las transformaciones de la pronunciación desde la época latina a la actual) (Manual, $\$ 5$ ), es en don Ramón una ciencia fundamentalmente fisiológica $-\mathrm{y}$ no acústica- y sicológica. Lo primero es consecuente con su observación de que «los gramáticos antiguos rara vez hacen un análisis fisiológico de las articulaciones que nos permita saber con toda exactitud cómo se pronunciaban" (ibid.), insuficiencia que él trata de salvar cada vez que le es posible. Lo segundo se hace patente en su oposición constante a cualquier explicación mecanicista de los cambios fonéticos, mediante lo que él mismo llama una «explicación expresivista» de los mismos:

"Tratando de fonética, hasta ahora, nos hemos fijado todos demasiado en los fenómenos de la inercia, del menor esfuerzo, y demás fenómenos de abandono o descuido en la enunciación, mientras, por el contrario, hemos olvidado los fenómenos de expresión y realce, que son más interesantes" (Origenes, p. 127, 11. 2).

Así, por ejemplo, e intentando reparar dicho olvido, cuando Bruneau, al dar cuenta de la diptongación, asegura que sil se peut que la langue ou les lèvres n'atteignent que progressivement la position exacte requise par la voyelle; il se peut qu'elles quittent cette position avant la fin de la voyelle; dans le premier cas il y aura tendence au développement d'une diphtongue croissante; dans le second cas la diphtongue sera décroissante" (ibid., p. I24, n. 2), don Ramón acota que

resta explicación [...] mira el diptongo como un fenómeno de inercia $y$ abandono, cuando es ante todo un fenómeno de realce y énfasis. Creo que la diferenciación del timbre en la vocal que se diptonga no procede de pereza de los órganos, sino, muy al contrario, de exageración articulatoria, aunque a ésta pueda seguir relajación\# (ibid.). 
Idea sobre la que vuelve más adelante con una insistencia muy decidora de la tenacidad y firmeza con que defendía sus puntos de vista:

-Los diptongos de origen romance son en gran parte nacidos de una fuerza de expresiviclad que anima la vocal acentuada. y que la descompone ell dos elcuentos diforenciados. La explicación simplemente necíuica, de inercia, que sucle aducirse, no satisface al mayor esfuerzo articulatorio que supone la diferenciación diptongante. Preciso es que en fonletica demos mayor cabida a los wóviles psicológlcos, y 110 atenernos sólo a los fisiológicosı (ibid., p. 127; el espaciado es mio).

Pero donde los "móviles psicológicos" se hacen más evidentes es, a juicio de Menéndez Pidal, ell los "cambios fonéticos esporádicos» (asimilación, disimilación, ultracorrección, etc.), a los cuales les dedica todo un capítulo (el IV) en su Manual; es decir,

"cambios fonéticos que no son regulares o normales como los anteriores [los regulares], sino que obraron u obran esporádicamente, unas veces sí y otras no, sobre los soniclos colocados en iguales condiciones dentro de las varias palabrası $\left(\$ \sigma_{4}\right)$;

cambios esporádicos que

"sov de naturaleza visiblemente distinta de la de los regulares, por fuudarse en una intervención más pronunciada de las a cti $v$ i d a des ps 1 quicas individuales que desvian la articulación de un modo brusco, muy diverso del modo gradual o evolutivo en que se suele aiterar la articulación en los cambios regularesi (ibid.; el espaciado es mio).

Por todo lo cual «acaso nos revelan la vida psíquica del lenguaje con más variedad e intensidad que los cambios regulares" (ibid.; el espaciado es mío).

Dentro de los cambios fonéticos esporádicos, don Ramón atribuye particular importancia a la inf 1 u encia an a lóg ica, tan reveladora de la intervención del hombre, por lo que hace a su parte menos animal, en el fenómeno lingüístico; a esa misma ufuerza sistemática» tan exaltada por los "Junggrammatiker", y que nuestro autor explica con inigualable claridad así:

- El souido y el pensamiento que formau el lenguaje son de naturaleza tau distinta, que están entre sí, la mayor parte de las veces, en la relación del signo a la cosa significada, es decir, en una relación puramente arbitraria, establecida por una larga tradición, siendo por lo común indiferente cualquier sonido para representar cualquier idea, y cualquier idea para encarnar en cualquier sowidow, (ibid., § 68);

en todo de acuerdo con la doctrina saussuriana. 
4Sin embargo, hay nuchos casos en que el hablante no se limita a usar de la palabra como de signo indiferente fijado y animado por la tradición, sino que la contamina con alguna otra representación psíquica concurrente, que viene a alterar la articulación de la palabra. Esta deformación fonética vienc del deseo, por lo común inconsciente, de h a c e r r e s a $1 \mathrm{t}$ a $\mathrm{r}$ con el soniclo la analogia verdadera o supuesta que se descubre cntre dos o mús voces, avecinando el sonido de una al de otra ["en vez de decir en una enumeración "primarius" y "postremus" se dijo en el vulgar "primarius" y "postrarius", de donde primero y postreron], o confundiendo en una dos voces de significado análogo ["para designar el 'escalón' se podian ocurrir dos derivados de "pedem": "pedalis" o "*pedilis" y "pedaneus", que tenian acepción semejante y que podian designar el tramo; de la reunión de ambos derivados se hubo de formar "*ped(i)laneus y peldañon] (ibid., $\S 68$; el espaciado es mio).

Pero tener ell cuenta los concomitantes sicológicos de los cambios fonéticos, no significa - cargando la balanza hacia un solo lado- descuidar o menospreciar los factores fisiológicos. De ninguna manera:

"Ial historia de la articulación del latín [hay que entenclerla como] expresión de un fenómeno espiritual, claro es, pero sometida a muy determinallas $n$ or $m$ as $f$ is $i$ ologi as y a muy poclcrosas corrientes tradicionales que obraron sobre la colectividad hispánica, dentro de linuites geográficos y cronológicos determinados" (ibid., § 64; el espaciado es mio).

$\mathrm{Y}$ lo que es más, "el descubrimiento de esas leyes fonéticas ha asentado el estudio del origen de las palabras sobre una base firme capaz de servir al trabajo científicon (ibid.).

Otro aspecto que llama la atención dentro de la Fonética de la obra de don Ramón, es que, aunque no hizo Fonologia, en el sentido actual del término, no por eso dejó de advertir la influencia que puede tener a veces un fenómeno fonético en el significado de una palabra. Así, por ejemplo, cuando nos informa que en francés, italiano, portugués y catalán "la distinta abertura de la vocal depende de la etimología y puede cambiar la significación de la palabra", y que, "por el contrario, en español las diferencias de abertura en las vocales no dependen de la historia de la palabra, ni tienen valor significativol) (ibid., $\S 5_{2}$ ). Pero hay que reconocer que observaciones de esta indole son aisladas, pues su preocupación, como lo hemos dicho, era la Fonética, y mejor aún - como corresponde a un hombre en que se encarnó la Historia- la Fonética histórica. Por esto no debe desorientarnos el que más de una vez hable de fon e m a (Origenes, $\S 22 ;$ Manual, $\S \S 66_{3}, 77$, etc.) y de "dificultad fonológica» (Origenes, $\S 22$ ), pues estos términos tienen aquí el mismo sentido con que P. E. Guarnerio (citado por Menéndez Pidal en Orígenes, p. 111, n. 3) publicó en IgI8 su Filologia 
romanza; esto es, el de Fonética histórica, que no otro es tampoco el sentido que tradicionalmente han dado los ingleses a "Phonology".

I.2.2.I.2. En su Morfologia es interesante destacar algunos aspectos de su doctrina - doctrina a la que se tiene acceso más por su aplicación de la misma que por una formulación explícita- que, aunque corresponden en general al pensaniento tradicional de la gramática española - pero no necesariamente académica-, revelan en algunos casos preferencias por una orientación, y en otros, por otra, y alguna influencia de gramáticas extranjeras.

La Morfologia —en todos sus estudios gramaticales- está organizada sobre la base de lo que él prefiere llamar upartes del discurson (Cantar I, $\S \S 202_{2}$ y 205; Manual, $\S 73$ ), a la manera francesa ("parties du discoursi), heredera de los gramáticos alejandrinos, y no (partes de la oración", conforme a la tradición española, continuadora de la latina ("partes orationis"), expresión que don Ramón reservó, al parecer, para "sujcto", "predicado" y "complemento"; cs decir, para la sintaxis (Cantar I, $2_{205} y_{7}$ ). Lista preferencia por cl francés, que se reitera en el hecho de hablar de c o 11 di c i o 11 a 1 (Cantar I, § Ioo; Manual, § I23) cuando la Acadenia Isspañola aún consideraba esta forma verbal como la tercera del pretérito imperfecto de subjuntivo (antes de transformarla, en I9I7, en el (modo optativon), es consecuente con su profundo conocimiento y cariño por esta lengua, cuya forma antigua, junto con el antiguo provenzal, fue a estudiar a Toulouse en $1898, y$ cuya épica investigó "como guía para la española" (Conde, $M . P ., \mathrm{p} .4 \mathrm{I}$ ), hasta darle a la Historia de la literatura románica, a los noventa años de edad, esa obra de impresionante erudición y originalidad que es La Chanson de Roland y el neotradicionalismo (orígenes de la épica románica) ${ }^{1}$.

De la comparación de sus estudios gramaticales más completos, en relación con sus "partes del discurso» (clases morfosemánticas de palabras, como ha sido lo tradicional, y no sintácticas, ya que no en vano las estudia en la Morfología), se obtienen los siguientes resultados en cuanto a su número $\mathrm{y}$ denominación:

Cantar I (IS93-I908), 8 partes: artículo, nombre, pronombre, verbo, adverbio, preposición, conjunción, interjección ( $\$$ 60-I08);

Mannal (I904), 4 partes: nombre, pronombre, verbo, partícula ( $\$ 73)$; Origenes (I926), 7 partes: nombre, artículo, pronombre, verbo, adverbio, preposición, conjunción ( $\$ \S 6 \mathrm{I}-79$ ).

Se ve, pues, que en ningún momento Menéndez Pidal coincide con la Academia de la Lengua en el número de "partes", ya que no tiene

1 Madrid, I959. 
en cuenta el participio-que esta institución sólo incluye en el verbo a partir de I920-, y en el Manual y en los Origenes prescinde (sin duda por razones prácticas, y no teóricas) de la in t e r j e c c i ón, que desde I77I siempre ha estado presente en la Gramática académica.

El a rticulo sin más es el "definido»; el "indefinido" es sienpre calificado como tal (Cantar I, § II8), o simplemente no se lo menciona (como ocurre en las otras dos obras). En esto don Ramón se ajusta fielmente a la doctrina académica, cuya definición de artículo (ed. de I93I, $\S 77)$ excluye de hecho al artículo indefinido.

El no m b re en el Cantar I y en el Manncal corresponde genéricamente al "sustantivo", al "adjetivo" y al "numeral", de acuerdo con Nebrija (v. supra p. 250, n. I), Correas (v. supra p. 248, n. I) y la Academia hasta la edición de su Granática de 1874 , edición en que "ha disgregado el adjetivo del nombre, y constituido con aquél una nueva parte de la oración". En los Origenes el nombre sólo incluye al sustantivo $\mathrm{y}$ al adjetivo.

Pa rtícula, a su vez, abarca, en general, las "palabras invariables" (《indeclinables», dirán los gramáticos latinizantes), es decir, aquellas que como el adverbio, la preposición, la conjunción y la interjección (cuando se la toma en cuenta), por no tener flexión, no alcanzan la categoría de "partes». Tal es el pensamiento implicito en esta distinción terminológica, que don Ramón comparte con Cristóbal de Villalón ${ }^{1}$, el Brocense ${ }^{2}$, Gonzalo Correas y, menos distante de nosotros, Vicente Salvá ${ }^{3}$, pero que es ajena a la doctrina académica. Es inevitable no asociar esta clase residual de "partícula" (o "partezilla", como decia

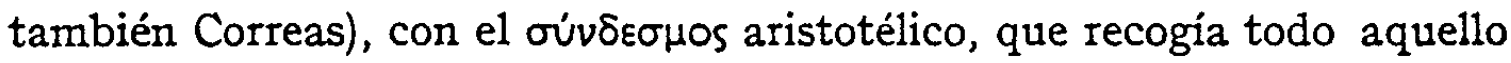

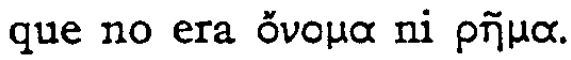

La morfología del ve r b o le plantea igualmente otro problema terminológico, que esta vez resuelve con ayuda de una gramática extranjera:

"Para abreviar, aplicando caprichosamente dos términos de la gramática alemana, llamaremos formas verbales $f$ u $\mathrm{r} t \mathrm{e}$ s las que tienen el acento en el tema (áma, dije) y d é bi les las que lo tienen en la terminación (amaimos, amába, decia)", (Manual, § 106).

La preposición nos lleva otra vez a su "explicación expresivista" de los hechos del lenguaje: "No son [...] razones fonéticas, sino

1 Gramática castellana, Amberes, 1558 .

2 Minerva, Salamanca, 1587.

3 Gramática de la lengua castellana, Paris, 1830. 
otras p s i cológi c a s y sintácticas, las que más contribuyeron a la pérdida de la declinación latinal (ibid., $§ 74_{2}$ ), pues la preposición se generalizó, ya en latín vulgar, "por más cómoda y expresiva» (ibid.).

Pero hay que insistir en que este sicologismo, tan del gusto de don Ramón, no se opone en él a las exigencias que le demanda una gramática cientifica: la existencia de leyes. Por el contrario, sabe muy bien que

"aunque las desinencias de flexión obedecen en principio a las le yes f o néticas [...], obedecen también a otras le yes un orfologicas, y es preciso ir examinando en cada caso la resultante del cruce de estas dos fuerzas: (ibid., $\S 73$ ).

Admirable observación que recuerda ya a la moderna morf o nología.

I.2.2.I.3. 'La s in $t$ a $x$ is, que en el Cantar I ( $\$ \S 20 I-2 I 0)$ y en los Origenes ( $\$ 80$ ) se centra en un capitulo destinado al uorden de las palabras», pone de manifiesto una curiosa proliferación sinonímica en el uso de la terminología gramatical.

Sinónimos absolutos son, por ejemplo, "oración", "proposición", ufrase" y "cláusula». O r a ción, conforme a la tradición española; p r o p os i c ió u y f r a s e, de acuerdo con la francesa, y clá u s u 1 á, según la costumbre inglesa, como lo manifiesta, por ejemplo, la obra de W. H. Chenery, Object-pronouns in dependent clauses (I905), citada por el propio Menéndez Pidal (Cantar I, p. 406, n. I). Una muestra de cláusula, entre otras, es don Rachel e Vidas a nyo fid besaron le las manos (ibid., § 202, ). "Proposición" $y$ ufrase» alternan estilísticamente incluso en un mismo párrafo:

4Estos auxiliares no pueden ir en el primer lugar de la proposición, de manera que si encabeza la frase el tiempo compuesto con ellos, el participio debe preceder: obrado es con oro" (ibid., $\S 205_{8}$ ).

$Y$ "oración» y "frase» aparecen en una misma serie, en que junto a "oración causal" y "oración final" se habla de «frase concesiva» (mal que uos pese, 'aunque os pese mal'; ibid., § 2IO). Y (frase interrogativa» denomina al siguiente ejemplo: ¿do son vuestros esfuer fos? (ibid., $\S 20 \mathrm{I}_{6}$ ).

Siguiendo antiguos hábitos españoles, distingue entre "oración simple» y "oración compuesta» (ibid., § 203), y en ésta, cuando lo es por subordinación, una "oración principal" y otra que en el Cantar I tiene nada menos que siete demominaciones: oración subordinada ( $\S 20 I_{9}$ ), oración dependiente $\left(\S 2 \mathrm{IO}_{2}\right)$, oración secundaria $\left(\S 20 I_{8}\right)$, oración in- 
cidental ( $\left(205_{2}\right)$, proposición subordinada ( $\left(205_{7}\right)$, proposición complementaria $\left(\S 2 \mathrm{ro}_{1}\right)$ y cláusula dependiente $\left(\S 205_{6}\right)$.

Quizás convenga aclarar que lo que don Ramón llama "oración incidental" (quando él lo oyó, pesól, § 2052), no se corresponde con la "proposición incidente" de Bello (Bello, Gram., § 307), pues ésta es siempre adjetiva "explicativa» (y no "especificativa», ni menos adverbial), que es el sentido que habitualmente tiene en la gramática europea.

También identifica $\mathrm{predicado}$ y a $\mathrm{tributo}$ (Origenes, § 80), dándole a ambos el sentido académico de 'predicado nominal': "el verbo ser con predicado sigue parecida regla "(Cantar I, § 2059). Y los ejemplos son inequivocos: grandes es predicado en grandes son los gozos (Cantar I, $\S 20 \mathrm{I}), \mathrm{y}$ castigatore es atributo en castigatore fueret (Origenes, $\S 80$ ).

"Régimen" y "complemento" alternan libremente (Cantar I, § 202). $\mathrm{Y}$ son igualmente sinónimos: "régimen directo" (Cantar I, § 20I), "complemento acusativo" (ibid., § 202) y "objeto directo" (Origenes, § 80).

Al hablar de complemento, es curioso que, mientras cita específicamente al "complemento acusativo" y al "complemento dativo" (Cantar I, § 202), cuando tiene que referirse al "complemento circuns- . tancial" no lo haga con esta denominación ni con ninguna otra especifica, sino que lo mencione como "complemento» sin más (ibid.), o como "complemento con preposición" (ibid.), "régimen preposicional" (ibid., § 203), o "régimen dependiente de preposición" (ibid., § 20I).

I.2.2.2. Queda claro que don Ramón en ningún momento estuvo preocupado de perfilar -explícita o implícitamente- una teoría gramatical simple, exhaustiva y coherente, conforme a las exigencias actuales, y mucho menos de hacerse de una terminologia rigurosamente univoca, lo que, por otra parte, y dada su extrordinaria claridad expositiva, en nada le perjudicó para la consecución de sus fines: hacer una minuciosa y correcta descripción e interpretación de los fenómenos lingüísticos.

I.2.2.3. Con todo, no deja de extrañar que en la "Gramática" de los Origenes haya un apartado ( $\S \S 8 \mathrm{I}-85$ ) dedicado a reseñar los trabajos lexicográficos de los siglos tenidos en consideración, pues sólo el Códice 60 de San Millán, más conocido como "Glosas emilianenses», tiene relación, y muy tangencialmente, con la gramática:

"Además de las glosas, el monje anotador marcó con una + el comienzo de cada oración gramatical (?), señaló con letras $a, b, c, d$, etc., el orden lógico de las palabras, para deshacer el hipérbaton, y declaró por medio de relativos o sustantivos latinos el sujeto de los verbos que no [lo] llevan expreso, el oficio de los complementos verbales y el sustantivo que los pronombres representan" (ibid., p. 3), "por lo cual parece que se pusieron por o para un estudiante de gramática" (ibid., p. 382). 
Pero el estudio de don Ramón es netamente lexicográfico, y se denomina justamente "lexicografía».

I.2.3. En resumen, considerando en conjunto la labor gramatical de Menéndez Pidal, se la puede calificar de cientifica - moderna en su espiritu y realización-, especial, por referirse a la lengua española; aunque se ocupe comparativamente también de no pocos de los dialectos románicos no españoles; diacrónica, por orientarse preferentemente en el "eje de las sucesiones", según la fómula de F. de Saussure; descriptiva y explicativa a la vez, y taxinómica, como todos los estudios gramaticales llevados a cabo hasta el advenimiento de la gramática generativa y transformacional de Chomsky.

I.3. El fillólogo.

I.3.I. Es difícil deslindar, dentro de la copiosa bibliografia de Menéndez Pidal (unos 450 títulos), lo específicamente filológico, porque él siempre entendió que la filología, la historia, la literatura y hasta el folklore, eran inseparables. Es evidente que el espíriti que lo animaba es el mismo de Wolf, para quien, como se sabe, filología es

"el conjunto de conocimientos que, con los hechos, la ordenacion politica y la literatura de los pueblos antiguos, nos inforuman sobre su cultura, sobre la lengua, las artes, las cicncias, las costumbres, la religión, las caracteristicas nacionales, de tal modo que venimos a quedar capacitados para entender y juzgar con gusto y penetración sus diversas obras" ${ }^{3}$.

Con gusto y penetración, es decir,

-a fondo [...], gozándonos en penetrar el espiritu de su contenido con todos sus matices y haciéndonos así presente la vida antigua a fin de compararla con la de la posteridad" (ibid., p. I75).

$Y$ esto es justamente lo que ha hecho don Ramón, como bien lo notó C. Sánchez-Albornoz, a propósito de La España del Cid 2: "iQué admirable labor de creación para poner almas en seres extinguidos y vida y movimiento en escenas pretéritas" 3! Y lo mismo Azorín, como lo testimonian estas palabras suyas ", llenas de acierto y de emoción: "iMa-

1 Apud G. RIGH, Historia de la filología clásica, Nueva Col. Labor, Barcelona, 1967, p. 174 (cit.: Righi, Filol.).

2 Madrid, Plutarco, I929; $4^{3}$ ed. totalmente revisada y aumentada, I947.

3 El Sol, 9-III-I930.

- $A B C$, 26-III, 6-v, r 7-VI, 1930. 
ravilla de abolición del tiempo! ¡Matiz de angustia, sí, de angustia, al ver cómo de las profundidades de nueve siglos pueden ser traídos al presente, como si el tiempo no existiera, la muchedumbre de detalles de una vida! Y de una vida que parecía ya sumida en la abstracción, sin color y sin relieve. $Y$ aqui la tenemos: palpitante, anhelante, en estos días cle finales del siglo XI...».

I.3.2. No hay quien se haya ocupado de Wolf, que no haya tildado de excesivamente amplio su concepto de filología y, en consecuencia, de demasiado ambicioso su programa de trabajo filológico, para el cual, según su Enzyklopädie der Altertımewissenschaft, debe concurrir el esfuerzo nancomunado de 24 disciplinas distintas ${ }^{1}$. Sin embargo, es usual distinguir en el estudio filológico una rparte substancial y principaln: la critica y hermenéutica de los escritores, y, como "medios conducentes a ella", el estudio gramatical, estilístico, poético y literario de los mismos, que a su vez necesitará, como auxiliares, la labor paleográfica y la epigráfica (ibid., p. Io). Y de todo esto se ha ocupado don Ramón.

I.3.3. Se ha dicho que lo propio del trabajo filológico es "la crítica de los textos, la investigación de su autenticidad, el descubrimiento de las corruptelas, interpolaciones y lagunas" (Righi, Filol., p. I4), el estudio de las vicisitudes por las que ha pasado el texto original a través de la o las copias que se han hecho de él, porque filología es también "ese interés por conservar los textos, ese afán por fijar con exactitud los documentos, por establecerlos y documentarlos para poderlos describir fidedignamente y reproducirlos de un modo sensible como depósitos de la sabiduría cierta del pasadon (ibid., p. I3). Y esto es precisamente lo que ha llenado una buena parte - si acaso la mejor- de la larga y fructífera vida de Menéndez Pidal. Alli están para probarlo: La leyenda de los Infantes de Lara (v.supra p. 25I, n. 3), su primer trabajo importante en este sentido, con el que inaugura para España una nueva hermenéutica de la épica castellana y los métođos científicos (histórico y filológico) dominantes desde hacía ya largos años en la Europa de entonces; el Cantar de Mio Cid, obra cumbre de la filología de nuestros tiempos; la edición crítica y paleográfica de diversas "Crónicas»: Primera Crónica General ${ }^{2}$, redactada por mandato de Alfonso el Sabio hacia

1 W. Krol., Historia de la filología clásica. Col. Labor, Barcelona, 1928, p. 9 (cit.: Kroll, Filol.).

2 Primera Crónica General de España que mandó componer Alfonso el Sabio $y$ se continuaba bajo Sancho IV en I289. Madrid. Bailly-Baillière e Hijos, I906. 
I270; la Crónica de I344 (Segunda Crónica General) ', editada fragmentariamente; La Crónica General de $1404^{2}$, editada con variantes; la Crónica de Veinte Reyes ${ }^{3}$, editada parcialmente y también con variantes: "el trabajo filológico, sobre una gran masa de manuscritos de crónicas generales - nos confiesa-, era especialmente apropiado para mí por versar sobre textos de materia histórica que en sí misma me era grata" (Conde, M. P., p. 4I). Además, la edición crítica y paleográfica de algunas de las famosas "disputas» medievales: Disputa del alma y el cuerpo, $y$ auto de los Reyes Magos \$, compuestas en la seguuda mitad del siglo xir; Razón de Amor, con los denuestos del agua y el vino 5 , con reproducción facsimilar del manuscrito, de interés para el estudio del dialecto aragonés; Elena y Maria. Poesia leonesa inédita del siglo $X I I I I^{\circ}$, y luego otras ediciones, como "Roncesvalles". Un nuevo cantar de gesta español del siglo $X I I I$ ?, escrito en castellano con algunas influencias del dialecto navarro-aragonés, reconstituido por don Ramón "con seguridad y precisión admirables", basándose sólo en cien versos de "un estropendo pergamino" 8; Historia troyana en prosa $y$ verso", compuesta hacia 1270 y editada por don Ramón en colaboración con E. Varón Vallejo; el Poemra de Yúquf ${ }^{10}$, compuesto a fines del siglo xin o a comienzos del XIV, e importante para el estudio del dialecto aragonés, y un conjunto de otros textos medievales reunidos bajo el nombre de Reliquias de la poesía épica española "11, "dedicado -según don Ramón - a recoger y estudiar los restos que de ese género poético subsisten, definiendo, con ayuda de ellos, el concepto de poesía épica tradicional" (Conde, $M . P .$, p. G3), con un título que resume y revela con elocuente claridad el entrañable cariño de Menéndez Pidal por el "epos» vigoroso y heroico de la tradición española.

I.3.4. Detengámonos un poco en dos de sus trabajos filológicos fun-

1 En Reliquias, ( $r$. infra $11 . \mathrm{I} \mathrm{I}$ ).

2 Rev. de Arch., Bibl. y Museos, I903, IX, pp. 34-55.

3 En Reliquias.

- Rev. de Arch., Bibl. y Museos, 1900, IV, pp. 449-462.

s RHi., x905, XIII, pp. 602-618.

- RFE, I9I4, I, pp. 52-96.

- RFE., r9I7, IV, 1p. 105-204.

s A. Castro, apud Conde, $M . P .$, p. $23 \mathrm{r}$.

- RFE, Anejo XVIII, I934.

10 Materiales para su estudio. Rev. de Arch., Bibl. y Museos, r902, VII, pp. 9I-I 29, 276-309, 347-362; reeditado con muchas ampliaciones como t. I de la col. Filológica, Gramada, 1952.

11 Madrid, Espasa-Calpe, I95I (cit.: Reliquias). 
damentales: La leyenda de los Infantes de Lara y el Cantar de Mio Cid.

I.3.4.I. La Leyenda, obra premiada por la Real Academia Española de la Historia, consta de dos partes: la "Primera Parte" (pp. I-204, en la ed. de 1934) contiene el amplio y erudito estudio de la leyenda tejida en torno a la infortunada vida de los siete Infantes del Solar de Lara o de Salas, y la "Segunda Parte», la edición crítica de diversos textos. "El último capítulo sobre los Infantes, dedicado a los lugares y las tradiciones populares en ellos vivas, me lo dio mi gusto por el excursionismo" (ibid., p. 43), nos confidencia don Ramón; gusto que, como veremos más adelante, desembocará en la consolidación de un m é t o d o, el que con otros empleados por él, más la o b jeti vi d a d para encarar los temas y su ipropensión a preferir la di men sión ve $\mathrm{t}$ i c a l a la horizontal, cuando las dos son tan necesarias) (según su propia censura: ibid., p. 3I), constituyen la clave de sus aciertos científicos y del carácter definitivo de los mismos. Finalmente, un "Apéndice" incluye, entre otras cosas, "las genealogías [del linaje del Solar de Lara]" (pp. 432-436) y un "Glosario" (pp. 437-446).

La leyenda en cuestión, cuya vida sigue Menéndez Pidal, fijándose sobre todo en sus manifestaciones más populares (Leyenda, p. xi), tiene el mérito literario, entre otros, de haber sido uel primer grito de rebelión lanzado por el romanticismo en suelo español y de haber dado vida a obras de gran importancia" (ibid., p. xii).

I.3.4.I.I. Sobre los textos editados (romances, crónicas, comedias), el propio editor nos informa que uentre los romances no populares hallaremos siete que no figuran en la abundante colección de don Agustín Durán", y que de ellos reproduce cuatro que están inéditos (ibid., p. xiv). En cuanto a la publicación de los capítulos dedicados a los Infantes en la obra del Rey Alfonso y en sus ulteriores redacciones, nos dice literalmente, en un gesto de humildad que sólo los auténticos sabios son capaces de tener:

"Sé que en esta tarea habré cometido bastantes yerros de detalle, y algunos los reconozco ya; pero encontrarán disculpas en quien considere que éste es el primer ensayo de una edición critica de las crónicas castellanas...v (ibid., p. xv).

"Respecto al teatro, la serie de comedias de los Siete Infantes nos dará a conocer una inédita, anterior a las de Lope",

y de ella publicará largos trozos (ibid., p. xv). Queda claro, pues, que las fuentes de don Ramón, para el estudio de la leyenda, las constituyen tanto el romancero como las crónicas y el teatro. 
I.3.4.I.2. Si leyenda es "tradición oral apoyada a veces en hechos históricos ciertos", cabe preguntarse si esta de los Siete Infantes tiene fundamento histórico. Don Ramón nos responde asf:

... en 1927, con ocasión de un curso universitario donde exponda los temas épicos y la historia general del siglo $\mathrm{x}$, hube de encoutrarme con el suceso, olvidado [...] por nuestros cronistas e historiógrafos, en el cual se funda la gesta de los Infantes de Salast (ibid., p. 45I).

I.3.4.I.3. La excelencia de la obra, tanto por la originalidad de su método como por la profundidad de la investigación, escrita cuando Menéndez Pidal tenía sólo 27 años, había de originar un cúmulo de elogiosos comentarios. Morel-Iiatio ${ }^{1}$, por ejemplo, dice, al año siguiente de su aparición, que «M. M. explore les coins et les recoins de la littérature castillane du moyen âge, surtout les chroniques et les romances, pour atteindre enfin le but qu'il entrevoyait au commencement de ses recherches: la reconstitution (partielle, bien entendu, la seule possible) d'anciens $c$ a n $t$ a $r$ es perdus qui nous offrent la première forme que l'imagination populaire a su donner à la histoire des sept victimes d'une terrible vengeance castillane..... Gastón Paris ${ }^{2}$, a su vez, que "la vie de l'épopée castillane a été plus longue, plus riche et plus variée qu'on ne l'avait cru jusqu'ici. C'est la découverte et la démonstration de ce fait tout nouveau qui font le principal mérite philologique du livre».

$Y$ Menéndez Pelayo ${ }^{3}$, su maestro, observa que "la transcendencia de las conclusiones que de ella [la obra] se deducen [...] no se limitan al desarrollo de una leyenda, como del título pudiera inferirse, sino que alcauza a toda nuestra poesía épica y a sus relaciones más fundamentales con la Historia y con el teatrol.

I.3.4.2. Muchas son las obras de don Ramón que individualmente le habrian dado la inmortalidad en el Olimpo creado por las ciencias culturales, pero quizás la que mejor resuma las múltiples virtudes de investigador a cabalidad sea su edición del Cantar de Mio Cid. Texto, gramática y vocabulario, compuesta en I893, a los 24 años de edad, para tomar parte en un concurso abierto por la Real Academia Española de la Lengua (que la premió), y "refundida completamente» en I908, cuando todavía no cumplia los 30 .

En la edición "Obras completas", de Espasa-Calpe, $3 .^{n}$ edición, ocupa

1 Romania, ISy7, XXVI, pp. 305-320.

2 Journal de Savants, Mayo y Ju1uio (189S), pp. 296-309 y 321-335.

3 La España modema, Madrid, I898, CIX, pp. So-ro5. 
tres tomos: III, Vol. I (I954), Primera Parte: Crítica del Texto, y Segunda Parte: Granática, 420 pp.; IV, Vol. II (1954), Tercera Parte: Vocabulario, 484 pp.; V. Vol. III (1956), Cuarta Parte: Texto del Cantar y Adiciones y Enmiendas, 328 pp., lo que hace un total de I.232 páginas, sin contar trece de "Advertencias" e "Indice" del tomo III.

I.3.4.2.I. Ya tuve oportunidad de referirme a la "Gramática» y al "Vocabulario» de esta obra magistral, en cuanto trabajos gramatical y lexicográfico, respectivamente. Sobre la Crítica del texto, basta ver los capítulos elaborados por Menéndez Pidal para darse cuenta de la profundidad y exhaustividad del estudio realizado: comienza (I) por referirse al manuscrito del Cantar (su paradero, fecha de la letra, diversos correctores del Código, los éxplicit), sigue (II) con la filiación del único manuscrito existente (feclia del Cantar, el Cantar se transmitió por una serie de copias) y termina (III) con los recursos enmendatorios aplicables al códice único (localización del Cantar, metro del Cantar, asonancia en el Cantar, las Crónicas en su relación con el Cantar). Es decir, todo lo que la filología, como ciencia, exige rigurosamente.

I.3.4.2.2. El texto del poema aparece en una doble e dición: paleográfica ${ }^{1} \mathrm{y}$ crítica.

I.3.4.2.2.I. Con respecto a la primera, el propio don Ramón nos informa:

"IEn la presente edición reproduciré el códice único del Cantar de Mio Cid, con la exactitud paleográfica necesaria. Cuando sea preciso, justificaré la lectura que doy, mediante comparación con la que dieron los que antes que yo consultaron el códice único ${ }^{2}$.

Reconoce que "las ediciones modernas marcan una gradación en la perfecta lectura del manuscrito", pero "aunque las últimas sean excelentes», creyó necesario publicar la suya iporque el códice único ofrece complicaciones especiales, a causa de haber sido muy retocado en diversas épocas» (ibid., p. 908).

Nos dice también que su edición

«se funda en la distinción previa de varias manos de correctores que alteraron lo que Per Abbat habia escrito, y aspira a reflejar el estado primitivo del códice, [y que] no [adnutirá] sino lo escrito en letra de Per

1 Reimpreso posteriormente como: Poema de Mio Cid. Iacsimil de la edición paleográfica por don R. MLiníndez Pidar. Madrid, IybI. Un segundo volumen contiene la Edición facsimil del Códice de Per Abbal, conservado en la Biblioleca Nacional.

2 Cantar, III, p. 907. (Ver I. 3. 4. 2.). 
Abbat, y a veces algo de lo que puso el primer corrector de la copia, cuando la corrección de éste parece fundada en un original escrito, o cuando enmienda yerros evidentes del copista" (ibid.).

Finalmente, que la edición que nos da es un arreglo de la que publicó en 1898 y I900, rperfeccionada con la indicación, en tipo cursivo, de las letras embebidas en las abreviaturas (crie, commo, omne, etc.) (ibid).

I.3.4.2.2.2. Las advertencias hechas al comienzo de la edición crítica del Cantar (vol. III, pp. IOI7-IO2I), por su parte, son una clara expresión de algunos de los muchos valores éticos e intelectuales de Don Ramón: I) De su magnanimidad y espíritu de justicia para con sus antecesores, como se ve, por ejemplo, al enjuiciar la edición del Poema hecha por Andrés Bello, edición que - son sus palabras-

"es hoy todavia muy estimable por haber comprendido mejor que las siguientes el sistema de asonancias del Poema, y por la mesura y acierto de las correcciones que introduce en el texto de Sánchez. Sus defectos radicales en considerar el lenguaje del Cantar como de comienzo del siglo XII y en servirse de las Crónicas muy inoportunamente, son en parte explicables teniendo en cuenta que se trata de un trabajo antiguo, inacabado, y que no representa el pensaniento maduro ni las últimas jdeas del autor* (ibid., p. Ior 7 );

- al hacerse cargo de las correcciones de Restori, en sus Osservazioni sul metro, sulle assonanza e sul testo del Poema del Cid, cuando nos dice textualmente:

"Aunque no aceptemos sus fundamentos, siempre hallaremos, entre aquellas correcciones que Restori no apoya exclusivamente en ideas métricas, muchas felices que hoy subsisten firmes» (ibid., p. Ior8).

2) De su capacidad creadora, que no lo lleva pasivamente sólo a ureconocer todo lo que [le] parece útil de [los] trabajos anteriores", sino también a darnos una nueva reconstrucción del texto primitivo del Cantary (ibid., pp. I0I8-I9). 3) De su circunspección, mesura, ponderación, al declarar que descarta de la edición crítica "las correcciones más aventuradas, en especial las que sólo se basan en razones métricas" (ibid., p. I0I9). 4) De su criterio para decidir en puntos delicados, cuando confiesa:

-Eu cuanto al lenguaje, aspiro a dar una idea de la pronunciación del autor, no de sus grafias, que serian muy otras, especialmente en la representación de los sonidos palatales. Istos eran wuy imperfectamente representados en los varios sistemas gráficos usados en el siglo xir; por eso 
emplearé la ortografía que se generalizó en el siglo xrrr, como más exacta. Huiré de la uniformación de lenguaje (a la cual tiende Cornu), pues creo que la época se caracteriza precisamente por la lucha de varias formas concurreutes" (ibid.).

5) De su meticulosidad, que nada tiene que ver con lo que Romagnoli ha llamado (filología perezosa, $\mathrm{m}$ in i $\mathrm{t} u \mathrm{r}$ is t a y rutinaria, ignorante del fin a que debe servir: la penetración de los escritos transmitidos, su inagotable interpretabilidad” (Righi, Filol., p. I5), cuando establece:

"Señalaré con letra cursiva todo lo que añado al manuscrito de Per Abluat, lo mismo versos y palabras que letras olvidadas por el copista (picussan) o letras introducidas por mi para auticuar el lenguaje (sos). limpero no señalaré las letras que añado para reducir a la ortografía corriente del siglo xrir el mal sistema gráfico del autor o del copista ("lleguen", en vez de alegenn). Suponiendo siempre a la vista la edición paleográfica. tampoco advierto otras mudanzas gráficas, como de $v$ y $u$, de $j$, $i$ e $y$, que continuamente introduzcon (Cantar III p. roI9).

I.3.4.2.3. Su interés por el Poema del Cid - reflejo, entre otras cosas, de su interés por asistir al amanecer de la épica española- lo acompañó prácticamente toda su vida, a partir de I893, hasta el punto de aprovechar su luna de miel (I900) para revivir, a lomo de mula, con esa mujer admirable que fue doña María Goyri, el itinerario del héroe por las sierras de Burgos y Soria, aplicando lo que él llamó muy expresivamente su «método geográfico-excursionístico» (Conde, $M . P ., p .43$ ), nacido del amor a la Naturaleza -otro rasgo de romanticismo- en las añoradas aventuras infantiles por los montes astures, con su tío Juan, cazador de animales, y su hermano mayor, Juan también, cazador de romances (ibid., p. 20):

"Dejándome llevar de mi afición excursionistica - nos confiesa-, recorri los lugares nombrados en el Poema para comprobar su exactitud geográfica, como antes habia comprobado la historicidad de los personajes nombrados, y obtuve la conclusión de que el poeta escribia en tierra de Medinaceli [en la provincia de Soria] es decir, fuera de la Vieja Castilla, y que por tanto, usaba un dialecto no castellano" (ibid., p. 39).

Fuera de editar magistralmente el poema en rgo8, don Ramón lo publicó dos veces más, en ediciones anotadas: en IS98, como Poema del Cill ${ }^{2}$ y en Igr3, como Poema de $\mathrm{Mio}^{\circ} \mathrm{Cid}^{2}$ para la colección

1 Nueva edición, Madrid, Impr. de los hijos de J. M. Ducazcal.

2 Introducción, edición y notas, Madrid, edic. de la Lectura. 
"Clásicos Castellanos". Aparte de esto, varios fueron los artículos específicos que escribió para insistir en algunos puntos fundamentales o para agregar nuevos datos, que a veces representan autocorrecciones verdaderamente sorprendentes, como la que se refiere a la autoría del Cantar (v. infra: Dos poctas...). En orden cronológico: El poema del Cid y las Crónicas generales de España (I898) ${ }^{1}$, El Poema del Cid (Igro) ${ }^{2}$, El Poema del Cid. Valor artistico del poema (I9I3) ${ }^{3}$, Poesia e historia cir el Mio Cid. El problema de la épica española (I949) ", Fórmulas épicas en el Poema del Cid (I954) ${ }^{5}$, Dos poetas en el Cantar de Mio Cid (I96I) ' ${ }^{\circ}$, esto es, un poeta de San Esteban de Gormaz, autor de la primera redacción, hacia II05, y un poeta de Medinaceli, autor de una posterior refundición hacia II40; Cantar de Mio Cid (Ig62) ?, En torno al Pocma del Cid ( $\left.\mathrm{Ig}_{3}\right)^{8}$.

I.3.4.2.4. Pero conjuntamente con su preocupación por el $\mathrm{Cid}$ liter a rio, estuvo siempre la del $\mathrm{Cid}$ his tó rico, "-objeto, por otra parte, de la primera biografía escrita en la literatura hispanolatina 9, -, como se nota ya en el título de dos de los artículos citados. He aquí otros quc, en conjunto, enmarcan la vida cutera de Rodrigo Díaz de Vivar, destacando momentos importantes de su existencia o poniendo de relieve su enorme influencia en la España en que le tocó vivir: El Cid en la Historia ${ }^{10}$, Filologia e Historia. De critica cidiana ${ }^{11}$, De la vida del Cid. Notas sueltas ${ }^{12}$, Año y lugar del naciniento del Cid ${ }^{13}$, El solar del Cid 14, El Cid en Oviedo 15, "Mio Cid el de Valencia" ${ }^{16}$, El Cid campcador (v. supra 11. 9), "libro donde ahincadamente

\footnotetext{
RHi., I898, V, pp. $435-469$.

La Lectura, 1910, X, pp. 26r-282.

Revista de libros, I9I 3, I, pp. 5-1 I.

$N R F H$, I949, III, pp. II3-I29.

RPh., I954, VII, pp. 261-267.

Romania, I96r, LXXXII, pp. 145-200.

Gran Enciclopedia del Mundo, IV, Bilbao, 1962, Columnas 463-49o.

Col. "El Puenten, Barcelona-Buenos Aires, 1963.

- R. Mlenténdez Pidal, El Cid Campeador. Col. Austral, Buenos Aires, Espasa-Calpe, I950; 2." ed., I95I, p. I4 (cit.: Cid). Se trata de la Historia Roderici, proveniente del monasterio de Ripoll y descubierta a fines del siglo xvII.

20 iradrid, Jiménez y Molina, x921.

11 ZRPh., 1944, LXIV, pp. 21 I-232.

12 Rev. de Occidente, I926, XI, pp. I45-I67.

13 Bol. de la Real Acad. de la Historia, 1926, LXXXIX, pp. 8-9.

1s Revista de las Españas, Madrid, I (r926), pp. I-3.

15 El Carbajón, Oviedo, 26-1x-1926.

16 Valencia, Patronato del VIII Centenario del Poema del Cid, 1943, pp. I3-60.
} 
se trata de penetrar el espíritu de un héroe singularmente famoso" (ibid., p. I3), según explica don Ramón; El Cid y sus epitafios ${ }^{1}$, Autógrafos inéditos del Cid y de Jimena en dos diplomas de rogs $y$ Iror ${ }^{2}$ y La España del Cid, a que ya he aludido (v. supra p. 264, 11. 2). En suma, con palabras de Ricardo Rojas ${ }^{3}$, don Ramón «investigó los archivos, expurgó las crónicas, cotejó las gestas, clasificó el vocabulario, identificó personas y lugares, hasta elevar al Campeador un monumento tan durable en la ciencia como lo ha sido en el arte el del juglar anónimo que compuso el antiguo cantary.

r.3.4.2.5. No es casual en Menéndez Pidal este interés convergente por el personaje de leyenda y el hombre de carne y hueso: es que ambos son también personalidades convergentes, como las dos caras de Jano, y el hecho estaba alli, imponiéndose por su propia presencia, y no podía pasar inadvertido al ojo sagaz de quien no sólo fue el historiador del acontecer real de España, sino también de su literatura.

"Tienen los españoles - ha escrito don Ramón- la fortuna de contar en sus creaciones poúticas más de un personaje que pueda por excelencia representar condiciones egregias del carácter colectivo, y por otra parte, poseen abundancia mayor de personajes de la vida real a quienes poder atribuir tal representación. Entre todos, Rodrigo Díaz de Vivar, el Cid Campeador, merece con seguridad el primer puesto, pues aparece único en ser objeto preferente de una perdurable creación poética $y$ en asumir a la vez una elevada significación histórican (Cid., p. 13).

Pero hay más:

4la Historia y la Poesia - se entiende, la historia lealmente documentada y la poesía primitiva- nuestran una rara conformidad caracterizadora [al delinear la figura del Campeador], y eso que no hay héroe épico más iluminado por la Historia que el Cid. Es más: frecuentemente sucede que el carácter real del Cid es de mayor interés poético que el de la leyenda* (ibid., p. 18).

¿No se ha dicho que el hombre muchas veces es un personaje porque con frecuencia la vida es una novela?

A las dos causales anteriores - ser don Rodrigo un personaje real y poético a la vez, y coincidir la Historia y la Poesía ell su caracterización- puede agregarse una tercera: era imperioso para Menéndez

1 La Epoca, 5-VII-I92I.

2 RFE, Igr $8, \mathrm{~V}, \mathrm{pp} . \mathrm{I}-20$.

3 Menéndez Pidal, un joven filólogo, en Retablo Español, Bucnos Aires, 1948, página II 2. 
Pidal, por su fidelidad a los hechos, a su pueblo y a su propia condición de español, deshacer la negra e injusta imagen que del Cid habían pintado el jesuita Juan Frrancisco Masdeu -quien incluso llegó a negar su historicidad 1 - y más tarde, los arabistas José Antonio Conde ${ }^{2}$ y el lolandés Renicro Dozy ${ }^{3}$, situados en el upunto de mira árabe» de autores como el valenciano Ben Alcama (iIIIO?) y el árabe portugués Ben Bassam (IIog) -autor, por paradoja, del mayor elogio al Campeador hecho por un enemigo, elogio parcialmente grabado, por sugerencia de don Ramón, al pie de la estatua cidiana en Burgos (Conde, $M$. . $P$. pp. I4I-42) -, y reivindicar para el héroe -salvando al mismo tiempo "modernos descarríos" (Cid., p. I4) - el lugar que en justicia le corresponde entre los prohombres forjadores de la España de ayer y de hoy, conforme, a la postre, con la visión clarividente que de él tuvieron los dos poetas de la primera mitad del siglo XIr que cantaron sus hazañas.

Irinalmente, creo que un móvil más de nuestro sabio fue, sin duda, su necesidad espiritual de sentir como vivo y real cl símbolo que encarnaba tantas virtudes castellanas; por último, virtudes de la raza. ¡Cómo dejarlas relegadas simplemente al plano de la mera ficción! ¿No fue acaso el Campeador - para él- nada menos que el théroe titular del pueblo español" (ibid., p. Ig), el "héroe representativo español» (ibid., p. 20), "el más genuino héroe español" (ibid., p. 2I), el théroe que encarna las más altas cualidades humanas" (ibid., p. I4), el «héroe epónimo de cuán grande es Españan? (ibid., p. I5).

-El da nombre al pueblo español, y a las tierras españolas todas, que unidas en la obra cidiana se volverán a unir bajo los Reyes Católicos para lanzarse a la empresa del imperio hispánico-indianon (ibid., p. I5),

ya que fue él

equien, el momentos históricos de profunda evolución, inicia la hegemonia castellana sobre los otros reinos hispánicos, y afirma la prevalencia de la cristiandad sobre el islam (ibid., p. 22).

De aqui que su actitud ante el Poema, como ante la Leyenda de los Infantes de Lara, como en general ante cualquier texto épico que estudió,

1 Historia Critica de España, I783-1805, escrita en Italia sintomáticamente después de su expulsión de Ispaña, y antes, naturalmente, de ser expulsado también de Italia.

2 Historia de los árabes cu España, I820.

- Sobre todo en Le Cid. Textes et résultats nouveaux, de sus Recherches sur lhistoire politique et litteraire de l'Espagne pendant le Moyen Age, Leyden, 1849. 
haga recordar lo que Christian Heyne sostenia a propósito de la literatura clásica, que "para conocer lo antiguo en su totalidad hay que sentir de nuevo, hay que repensar, relnacer los sentimientos, la mentalidad y la acción antiguos en nosotros mismos" (Righi, Filol., p. I49). $\mathrm{Ni}$ más ni menos que lo que el idealismo vossleriano habia erigido en doctrina.

I.3.5. A once años solamente de la primera publicación de don Ramón, Menéndez y Pelayo, su maestro, podía decir de él, en una magnífica síntesis, que uen pocos años, y con publicaciones a primera vista fragmentarias y aisladas, ha transformado el aspecto de la Edad Media española, ha herido y penetrado dificultades y problemas que no se sospechaban antes de él, ha comenzado a resucitar un mundo épico, ha combinado y soldado formas de arte [de ciencia, en verdad] que hasta ahora parecian desligadas, ha dado luz al caos de nuestra primitiva listoriografía y al de los origenes poéticos y ha sometido a severo y escrupuloso examen lexicográfico, gramatical, histórico, los más antiguos y vcnerables documentos del habla castellana" ${ }^{1}$.

Asi pues, si visto en profundidad, filólogo es "una persona capacitada para descifrar, leer, interpretar, examinar con sus propios ojos y reconocer la integridad de un documento, para dar razón del mismo, juzgarlo, valorarlo o determinar con precisión su forma originaly (Righi, Filol., p. I2), don Ramón es sin lugar a la menor duda un auténtico filólogo, y de los mejores que ha producido no sólo España, sino el mundo contemporáneo.

\section{Menéndez Pidal y su concepción del lenguaje.}

2.o. Para mí es de toda evidencia que tanto el lingüista como el gramático, el filólogo, el historiador y el folklorista que había en Menéndez Pidal, actuaron siempre compenetrados de una c on ce p ción idealista del lenguaje, concepción que subordina a éste a la actividad - Évépyeı - espiritual del hombre. A las pruebas ya aducidas al respecto, será útil agregar otras.

2.I. Se sabe que ante las leyes fon éticas, por ejemplo, es posible detectar entre los lingüistas a lo menos tres posturas diferentes: la de los que las niegan sin más, la de los que afirmándolas las conciben como fatales y sin excepción, y la de los que las conciben como una 1902. 
realidad histórico-cultural $\mathrm{y}$, en consecuencia, dependiente de la voluntad humana. Esta última es la que fluye del pensamiento lingüistico de don Ramón:

iI a geografia dialcctal moderna - ha escrito- nos ha revelado el principio de que cada palabra ticne su historia aparte, por donde se quiere concluir que no existen lcyes fonéticas, sino historia de palabras. El estudio de la crowologia en los documentos nos revela lo mismo, que cada palabra tiene su historia; pero nos dice, además, que la suma de la historia de cada una de esas palabras nos da la historia de la constitución de una ley fonética* (Origenes, p. 93).

Tales leyes, entonces, existen, pero no hay que caer en el error unaturalistan de identificarlas con las leyes naturales:

"Basta decir que una ley lingüistica no se establece sobre hechos 11 a $t$ urales, sino solste hechos $h$ is $t \delta r$ icos perfectamente individualizados, que no lan ocurrido más que una vez en el curso de los siglos" (ibid., p. 53I).

2.I.I. Lo anterior no se contradice, por cierto, con el carácter natural y espontáneo de los cambios fonéticos:

"Todos los cambios fonéticos son naturales y espontáncos —claro está-, y todos pueden darse en todas las lenguas, pues se fundan en la fisiologia y en la psicologia de la elocución, que son semejantes en los holubres de cualquier lengua; todos los cambios obedecen a idénticos móviles de menor esfuerzo, de asimilación o disimilación, de equivalencia acústica, de evitación de conflictos homonimicos; pero esos cambios, tan naturales que son, no por serlo, se dan en todos los idiomas, no son fatales, sino muy al contrario, no se dan ordinariamente, porque una fuerza histórica de corrección tradicional les impide actuar; cuando por rara excepción actúan, es porque en cada caso concurren circunstancias particulares, no de his toria natural, fisiológica, igual para todos, sino de historia li i m a n a, circunstancias que rara vez se dan semejantes para dos pueblos diferentes y que debemos buscarlas, bien en la historia de las relaciones lingüísticas entre dos pueblos, causa frecuentemente impulsora de los cambios, o bien en otros varios influjos sociales externos que actúen sobre el idiona, o bien en las necesidades internas, estructurales, que cada idioma experimenta, obligándole a poner en relación cualquier tendencia fonética con el sistenna general de cada idiomar (Encicl., pp. LxxuI.STVi).

Es interesante ver, de paso, cómo don Ramón - listoricista, diacronicista - no vivió ajeno al estructuralismo, por esencia sincronicista; es que no existía para él, entre estructuralismo e historia, 
ninguna antinomia, sino - como era de esperarse de un historiadoruna subordinación de aquél a ésta, según lo deja establecido en este postulado metodológico:

-Tin la mayoria de los casos, ante un cambio linguiistico, deben examinarse primero las posibilidades de explicación histórica que se ofrezcan; una primera tradición histórica precede a la elaboración estructural, es su punto de arranque y, por lo tanto, la condicionan (ibid., p. cix).

2.I.2. Así, pues, las leyes fonéticas - según lo habían señalado también Schuchardt y Bréal, entre otros- no son "necesarias, fatales, al igual de las leyes de la naturaleza", como quería Schleicher, ni «inexceptuales", como pregonaron después los neogramáticos, según los cuales «debemos concluir [por ejemplo] que soldau [< soldado] se hará soldo, quieran o no quieran los que hablan" (Nuevo valor., p. 489). Por encima de esta "necesidad" ineludible está el sentimiento lingüistico del hablante, que don Ramón, como Vossler, identifica con el «estético»: Iil «sentimiento linguiistico de desagrado" que nos produce la evolución de unas determinadas formas [soldí, por ej.],

"pesaria incesante sobre esas formas, si ellas intentasen surgir en el habla culta, y ahora que la literatura tiene nucho más fuerza que en la época de origenes, ese desagrado promoveria continuas reacciones que tenderian a evitar la evolución y a mantener las formas tradicionalesy (ibid.).

Por esto, el modo más adecuado para indagar en los comienzos de nuestra lengua es

"penetrándonos en lo posible del espiritu de aquella remota vida pasada, inspirándonos en la in te n c ión es tét i c a de los hablantes de entonces, según estuviesen dominados por corrientes de cultismo o vulgaridad, cle arcaismo o neologismo, de énfasis o de abandono de la expresión (Origenes., p. ix; el destacado es mio).

Obsérvese que no es otro que "el gusto lingüistico» quien, por ejemplo, desecha la $f$, prefiriendo horno u orno a forno cuando

"empieza a manifestarse oscuramente en la región cántabra durante las épocas primitivas, y después por siglos y siglos dirigió el lenguaje de innumerables generaciones que al conforwarse a esa norma obedecian en cada tiempo a diversas causas de predilección hacia ellas" (ibid., p. 533).

Pero curiosamente, la misma regularidad con que éste y otros hechos semejantes se producen, ha desorientado a más de un investigador, 
como Meillet, Vendryès, Cuervo, por ejemplo, a quienes les ha parecido que el lenguaje está regido "por leyes independientes de la voluntad humana", debido a que "en multitud de casos, los resultados globales no dejan ver la iniciativa individual" (Unidad, p. I95).

2.I.2.I. y lo dicho 110 es todo:

-Vale la pena qute chl (sto nos detengamos algo - 110s aconseja don Ramón- Aún reaccionando frente a los neogranáticos [y frente a los nuaturalistas, por supuesto], tampoco cs favorable respecto a la voluntad del hablante la escuela de Ginclbra; lierdinand de Saussure, aunque reconoce que toda innovaciou evolutiva de la lengua tiene su raiz en el habla de los individuos, afirna, sin embargo, por otra parte, que la lengua, como institucion social, es algo rexterior al inclividuon, independiente de él, es un caudal depositado en el cerebro de cada hablante y usituado fuera de la voluntad de los depositariosn. De modo semejante, A. Sechehaye se siente inseguro cuando muestra tenıor de ser tachado de respiritualismo (sic) optimista, favoreciendo el factor individual a expensas del factor colectivon, y si reconoce que toda innovación lingüistica parte de alguien, sin embargo, repite que la lengua econstituye un objeto exterior al individuo, y escapa a su influencia", pues obcdece a "fuerzas que operan a tientas... a través de la incousciencia de tura acción colectivan. En este modo de ver el hecho social, el ingreso de lo inclividual en la csferat de lo colectivo no está visto con claridad en la por tantos títulos excelente construcción liuguilstica de la escuela de Giucbra. También, a nombre del estructuralismo, V. Brøndal da como un eaxioma que una parte esencial de la evolución lingüistica, en particular los cambios fonéticos fundamentales, se opera inconscientementer. NÍs tajantemente, en el Círculo Lingüistico de Praga, H. J. Pos llega a decir que tla misma finalidad inconsciente que domina al organismo humano actúa en la realidad nat u ra 1 de una lengua dada*; donde el autor no queda lejos del pensamiento de Schleicher, las lenguas como sorganismos naturales"; otros hablan de la lengua como una especie de consens us o m n i u m misteriosor (Nuevo valor, pp. 489-490).

-Pero si pasanios a otra actividad colectiva, la canción popular tradicional, poesía manejada por muchisimos, innumerables repetidores, y no en un acto único, sino poesía evolucionante a lo largo del tiempo, entonces ya la crítica piensa en el misterio creador, en wel alma del pueblon, en oscura upoetización comuual, en ufenómeno sociológico extraño al individuo", etc.; y sin embargo, si se estudian cientos de variantes de una canción tradicional (cosa que muy pocos han hecho), se ve que las despreciadas y desatendidas variantes no aparecen como algo misterioso o incousciente o ciego, sino como resultado de una constante $y$ reiterada labor individual, una insistente intención personal puesta en tensión poética* (ibid., pp. 490-491).

Y volviendo al lenguaje,

"si estudiamos pacientemente los áridos documentos notariales en que se pueden descubrir los lentos origenes de un idioma románico, sorpren- 
deremos la laboriosísima gestación de un cambio fonético a través de varios siglos, en que se producen multitud de formas vacilantes, acordes o enemigas entre si, que unas y otras nos revelan intenciones de llaneza o simple dejadez, de encumbramiento o simple esfuerzo, de corrección erudita o elegante, de ultracorrección pedantesca o zafia, lucha siempre de encontradns corrientes culturales; nada de ciega inconsciencia ni de fuerzas sociales misteriosas, siempre, como factor decisivo, el individuo, su voluntad expresiva en tensión o en abandonon (ibid., p. 491).

\section{I.2.2.}

"In conclusión, el lenguaje ciertamente es algo ajeno a la voluntad única del individıo, $o$ de $\mathrm{c}$ a d a individuo, pero tanto el más pequeño como el más grande cambio que ocurre en el idioma ["siendo éste un becho humano ${ }^{2}$ ] obedece siempre a la iniciativa [creadora] de algún individuo [que se desvia de lo habitual] y a la adhesion que a esa iniciativa prestan otros individuos, imitándola y reajustándola [creadoramente también] a su propio gusto [ni más ni menos que como kse propaga cualquier costumbre en un grupo humano, hasta hacerse propia de la mayoria" (ibid., p. 197)]; "por tanto, el resultado de muchos actos inclividuales, voluntarios y conscientes, aceptado por una colectividad, no es nada ajeno al individuo, ciego, ni mech́nico; y llegamos así a reconocer que el individuo por sí s o lo puede influir en el lenguaje de la comunidad, lo mismo que puede influir en unas elecciones por sufragio universal: captánclose adhesiones, (Nuevo valor, pp. 49r-2).

De este modo, pues,

"el gran poder que hoy adquiere el habla individual, y nuestra persuasión de que no actúan fuerzas ciegas en el lenguaje, nos dicen que este hermoso idioma, base de nuestra fraternidad espiritual, en el que se han expresado tantos genios e ingenios del antiguo mundo y del nuevo, este hermoso idioma modelado por nuestra voluntad, nuestra inteligencia, nuestra sensibilidad, nuestra fantasia, tiene siempre su vida y sus destinos puestos en nuestras manos" (ibid., p. 495).

A la luz de los hechos, no hay ninguna razón, entonces, para temer, como Sechehaye, la tacha de "espiritualismo"; por el contrario, "tengámosla a gala: no hay fuerzas ciegas exteriores al individuo» (ibid., p. 493).

No es nada fácil, por cierto, escapar aqui a la tentación de ver en esta vigorosa y claramente estructurada concepción de don Ramón, ese (individualismo personalista", de ribetes obviamente

\footnotetext{
1 Unidad, pp. I96-197.
} 
románticos, considerado con insistencia como un rasgo sicológico de lo español.

2.2. Como consecuencia lógica de tal posición, negó también la posibilidad de que fenómenos naturales (geográficos) ${ }^{1}$, políticos, etc., puclieran explicar los $1 \mathrm{i}$ mites $1 \mathrm{ing}$ ülsticos que establece la dialectología:

*No nos cansemos - nos recomienda- en buscar una época cuyas divisiones aduinistrativas (politicas, eclesiásticas o de cualquicr otra clase) nos expliquen los línites lingǘsticos que podamos suponer más antiguos y estacionarios; no encontraremos tal época. No la elcontraremos porque cada umo de esos limites es de época diferente que el otro, y su propagación se hizo en condiciones diferentes, alcanzando, por tanto, una extensión diferente. No la encontraremos, además, y esto es más importante, porque las relaciones culturales que determinan la difusión de un cambio lingüistico no se ajustan siempre, ni mucho menos, a los limites políticos o administrativos, sino que los rebasan unas veces; y otras veces no los alcanzan, obedeciendo a corrientes de $c$ om e $\mathrm{r}$ c i o $\mathrm{h}$ u m a no mucho más varias y complejas que cualquiera de las que producen la administración politica, eclesiástica, cconómica, militar, etc. (Origenes, p. 544; el clestacado es mio).

2.3. Intinamente ligado a la manera de concebir la naturaleza de las leyes de cambio lingüístico, está el modo de ver -o de preverel futuro de la lengua española, considerada sobre todo en sus dos "habitat» más importantes: el peninsular y el hispanoamericano. Si se piensa que tales leyes son fatales, inexorables, como las leyes naturales, hay que pensar también que la fragmentación lingüistica de la Hispania de hoy será también fatal, "de ineludible cumplimiento", no importa cuánto tiempo se necesite para ello. $\mathrm{Si}$, por el contrario, se estima que las leyes del cambio lingüístico no son ineludibles, sino que dependen en última instancia de la voluntad humana, habrá que convenir en que tal fragmentación no será tampoco un hecho fatal: la suerte del español - su unidad o fragmentación - queda así entregada a la sola voluntad de los hispanohablantes.

2.3.I. Como se sabe, la primera tesis, nada optimista, ha sido enunciada y acogida particularmente por Bello ( $(847)$, Pott ( $(876)$ y Cuervo (IS99), sin que en los dos hispanoamericanos el hecho obedezca - ni muchísimo menos- a "tendencias separatistas", y la segunda, como era de esperarse, por Menéndez Pidal, quien se ha referido a ella más de

1 "Las montañas no suelen formar linnite lingǘstico" (Origenes, p. 449). Cp. "Los dialectos no tienen limites naturales", SAUSSURE, Curso, p. 320; "Las lenguas no tienen linuites naturales" (ibid., p. 324). 
una vez, pero sobre todo en La unidad del idioma ${ }^{1}$, y en Nuevo valor de la palabra hablada y la unidad del idioma?.

2.3.x.I. Andrés Bello, en el Prólogo de su Gramálica (IS 47 ) -verdadero manifiesto revolucionario para su tiempo y para hoy- denunciaba el peligro que constituía la aparición de una serie de imnovaciones, de "vicios», en la lengua española, de los cuales,

nel mayor mal de todos, y el que, si no se ataja, va a privarnos de las inapreciables ventajas de mu lenguaje común, es la avenida de neologismos de constrncción, que inuncla y enturbia mucha parte de lo que se escribe en Anérica, y alterando la estructura del idlioma, tiende a convertirlo en una multitud de dialectos irregulares, licenciosos, bírbaros; embriones de idiomas futuros, que durante una larga elaboración reproducirian en América lo que fue la Europa en el tenebroso periodo de la corrupción del latín" 3 .

$\mathrm{Y}$ tan fuerte era el temor de Bello con respecto a este "peligro" que uél ha sido - nos dice- el principal motivo que me ha inducido a componer esta obra [lia "Gramática"]" (ibidl., p. viii).

2.3.I.2. I'ederico Augusto Pott expresa los mismos temores al reseñar, en IS77, la segunda edición de las Apuntaciones criticas sobre el lenguaje bogotano ${ }^{4}$, de Cuervo, reseña ${ }^{5}$ en la que, después de hablar de las divergencias existentes entre el inglés de los Estados Unidos y el de Inglaterra, preguntaba:

"¿Podrá creerse que las lenguas del Iacio, trasladadas al suclo americano, cscaparán al destino que les imponen las leyes generales de la naturaleza?\# ${ }^{\circ}$.

Como muy bien anota don Ramón,

uno se trata aqui de leyes históricas, sino de leyes naturales. Pott escribe cuando el positivismo y darwinismo triunfantes habian inspirado, hacia

1 Madrid, 1944; reprod. en Castilla, la tradición, el idtioma. Col. Austral, Buenos Aires, Espasa-Calpe, 1945, pp. I7I-21 8 (cit.: Unidad).

2 Memoria del Segundo Congreso de Academias de la Lengua Española, Madrid, 1956, pp. 487-495 (cit.: Nuevo valor); reprod. en Cuadernos Hispannamericanos, 1956, núms. 78-79, pp. 253-262.

3 Gramática de la lengua castellana destinada al uso de los americanos [con notas de Culirvo]. Paris, R. Roger y I’. Chernoviz, I913, pp. vii-viii (cit.: Bello, Gram.).

- Con frecuente referencia al de los paises de Hispanoamérica, Bogotá, 1867-1872; 2." ed., Bogotá, 1876 .

- Publicada en los Göttingische gelehrte Anzeigen, $24^{-\mathrm{x}-1} \mathrm{~S}_{77}$.

- I a misma idea está ya contenida en la carta que, en latin, le habia enviado Pott a Cuervo, y que éste publicó como apéndice al Prólogo de esta misma edición de sus "Apuntaciones" (v. supra nl. 4). 
pocos años, a Schleicher su famosa concepción: la lingüistica era una ciencia natural, no era una ciencia cultural; las lenguas son un organismo con vida propia, que nacen, se desarrollan, envejecen y mueren, como todo ser viviente; un organismo regido por leyes de la Naturaleza, fatales, sin excepciones; 18 voluntad del hombre no puede intervenir en su desenvolvimientos (Unidad, p. 183).

2.3.I.3. Pero la verdad es querestas ideas alcanzaron al fin la mayor resonancia cuando las expuso en I899 un hombre rodeado del máximo prestigio científico, don Rufino José Cuervo" (ibid., p. I74), en la carta-prólogo del poema Nastasio del poeta argentino $D$. F. Soto y Calvo. Aqui Cuervo escribía:

-Poco lia me dio usted [Soto y Calvo] a leer en La Nación el parecer de un sabio lingüista francés [Louis Duvau, autor del prólogo a El idioma nacional de los argentinos, de Luciano Abeille, según cree Menéndez Pidal] sobre la suerte de la lengua castellana en América, parecer ya antes expresado por otros no menos competentes, y que a la luz de la historia es de ineludible cumplimiento" ${ }^{1}$.

«La influencia de la que fue metrópoli va debilitándose cada dían (ibid.) por nuestro constante alejamiento de la "madre Españan, de modo que

"carecemos [...] casi por completo de un regulador que garantice la autigua unifornidad. Cada cual se apropia lo extraño a su manera, sin consultar con naclie; las divergencias debidas al clina, al género de vida, a las vecindades y aúlı qué sé yo si a las razas autóctonas, se arraigan más y más y se desarrollan (ibid.). Itstamos, pues, en visperas (que en la vida de los pueblos pueden ser bien largas) de quedar separados, como lo quedaron las hijas del Imperio Romano (ibid., p. 52I).

Cuatro años más tarde ${ }^{2}$ reitera sus puntos de vista al afirmar que

res trivial noticia para los que hayan saludado obras de lingüistica que cuando un idioma se habla en territorios extensos, cuyos habitantes, separados por causas naturales, sociales o polfticas, no tienen comunicación frecuente ni obedecen a una idea superior que los haga considerarse a si propios como unidad, ese idioma se divide por fuerza en dialectos. Este hecho, reconocido por todos los lingüistas, naturalmente ha dado ocasión a que se tenga por cierto que tal suerte cabrá al castellanon (Cuervo, Obras,II, p. 563$)$.

1 Obras II, Clásicos colombianos, Bogotá, Inst. Caro y Cuervo, 1954, p. 520 (cit.: Cuervo, Obras II). İl t. I tiene las wismas especificaciones (cit.: Cuervo, Obras I).

2 En BHi., I903, V, pp. 58-77; reprod. ell Obras II, pp. 563-586. 
Y en Carta al Sr. Dr. Ernesto Quezada (Ig03) resume así

"dòos de las circunstancias que traen consigo la diferenciación dialéctica: 1) "La falta de una influencia unificadora, cómo la que ejercen las capitales, siendo focos de cultura, norma de los usos sociales y centro de la adiuinistración pública. Me atrevo a creer que ni Madrid ni ciudad alguna anericana tiene hoy tal prerrogativa en el conjunto de los pueblos que liablan castellanow. Y 2) "La falta de comunicación y trato constante entre los individuos que hablan la lengua* (ibid., pp. 560-561).

Pero no había de ser ésta la última vez que nuestro autor insistiera en el mismo predicamento; unos ocho años después, todavía escribía:

"¿Cabe en lo posible que corra el castellano la suerte del latin? 'Teóricamente la respuesta debe ser afirmativa. Falta saber los siglos que serán necesarios para llegar a ese punto, y las circunstancias históricas que lo apresurarán o lo retardarán.. 1

2.3.I.3.I. Sin embargo, este profundo convencimiento no lo tenía Cuervo catorce años antes de haberlo dado a conocer por primera vez, no obstante haber conocido para entonces el juicio de Pott. En efecto, en I885, y aludiendo justamente a la opinión de este autor, Cuervo aseguraba en el prólogo de la cuarta edición de sus Apuntaciones que

wo hay un dialecto bogotano, como lo hay veneciano o napolitano, asturiano o gallego [y quc] es infundado $\mathrm{cl}$ temor de que en la parte culta de Anérica se llegue a verificar con el castellano lo que con el latin en las varias provincias romanas" (apud Unidad, p. 178).

Pero no contento con vaticinar solamente, expuso en una apretada sintesis sus razones:

"La copiosa difusión de obras impresas, referentes todas más o menos a un mismo tipo, el constante comercio con la antigua metrópoli y el estudio uniforme de su literatura aseguran a la lengua castellana en América un dominio imperecederon (ibid.).

Que un hombre de ciencia cambie de posturas en el transcurso del tiempo, no tiene nada de extraño; por el contrario, es bastante habitual, sólo que rara vez conocemos de boca de su autor el porqué de dichas "mutaciones». Cuervo es una de esas excepciones:

1 Culirvo, Obras, I, p. 43, ell el Prólogo para la 6. ${ }^{\text {a }}$ ed. de sus Apuntaciones, Paris, I9I4, pero que sólo pudo ser incluido en la $7 .^{a} \mathrm{ed}$. [Bogotá, I939]. İl Prólogo es anterior al ${ }_{7} 7$ de julio de $I_{9 I}$, fecha en que murió el autor. Reprod. en Cuervo, Obras I, pp. I9-Ior. 
"Por ese tiempo [cuandn Pott expresaba sus ideas desintegracionistas] no tenia yo mayor conocimiento del estado del castellano en América, fuera de mi patria, ni habia meditado sobre el particular; asi me pareció iufundado el pronóstico. Con wás noticias después, he mudado de opinión, y sobre todo viendo que cada dia se acercan más a su cumplimiento los anumcios relativos al inglés, a pesar de las frecuentisimas comunicaciones que hay entre los pueblos que en América y Europa lo hablan, y de que alli se hacen copiosas y baratísimas ediciones de los mejores escritores ingleses autiguos y modernos; sólo porque falta la conciencia de la unidad, esa fuerza que de varios miembros constituye un organismo viviente. (Cuervo, Obras, II, pp. 563-564).

2.3.I.3.2. Así, pues, la creencia en la fragmentación aparece muy tarde en la mente del autor; pero - como Bello- absolutamente nada tiene esto que ver con un posible oculto deseo anticolonialista de independizarse lingülsticamente de España; Cuervo fue tajante en este sentido:

"Mientras tanto [no se llegue a la ineludible fragmentación], en obsequio de las facilidades que ofrece una lengua común para la trasmisión de las luces y para estrechar la fraternidad de pueblos de un mismo origen, y en vista de las ventajas que logra el arte de escribir aprovechúndose de un instrumento ya probado $y$ de una materia desbastada mediante una labor secular, es patente la necesidad de conservar la pureza de la lengua literaria. Si reconocida esta necesidad, se desea siuceramente mantener la unidad, tanto españoles como americanos han de poner algo de su parte para lograrlo" (Cuervo, Obras, I, pp. 43-44). "Yo, por mi parte, declaro que, aunque juzgo inevitable la disgregación del castellano en época toclavia distante, procuraré siempre escribir conforme al tipo existente aún de la lengua literaria, aunque de él ocasionalmente se aparten los españoles o los americanos: (Cuervo, Obras, II, p. 562).

2.3.2. Coino se ha visto, dos son los considerandos más socorridos que se alegan en favor de la inevitable fragmentación del español: - I) el ejemplo vivo de la fragmentación lingüística de la Romania, y 2) la confianza absoluta en el cumplimiento inexorable de las leyes del cambio lingüístico, pues uni los más insignes escritores ni poder humano alguno son capaces de atajar el movimiento natural del lenguaje" (ibid., p. 572). Ahora bien, contra ambos arremete Menéndez Pidal con toda la fuerza de su sabiduría para garantizarnos la unidad del imperio lingüístico español por los siglos de los siglos.

2.3.2.I. La comparación con el latín-nos enseña-

nes muy al contrario que pesimista: cuando se fragmenta el imperio romano, los pueblos latino-hablantes caen en un aislauniento y en un colapso de vida intelectual de que no hay semejante en toda su historia, mientras que des- 
pués de fragmentado el imperio español, los pueblos de habla española se comunican hoy $\mathrm{y}$ manticnen una vida literaria con actividad infinitamente mayor que antes. No se hable más de esta famosa comparación" (Nuevo valor, p. 488).

Es decir, que "las circunstancias de ahora son no sólo del todo diferentes, sino completamente opuestas a las [...] del comienzo de la Edad Median. (Unidad, p. I94).

2.3.2.I.I. Al aislaniento de entonces hay que oponer la constante intercomunicación entre los pueblos hispánicos de ahora, debido al extraordinario avance tecnológico en los medios de transporte y en los de comunicación; lo que no sólo ha favorecido el mayor alcance de la palabra escrita, sino -y sobre todo-- el de la palabra oral.

"Cuántos millones de cartas ha suprimido el teléfono, cuántos millones de folletos lia suprimido la radio, y cuántos miles de novelas dejan de entintar el papel para impresionar la película sonora! Quién sabe si la escritura misma llegará a arrinconarse como lenta y embarazosa" (ibid., p. 204). ${ }^{1}$

\section{Consecuentemente,}

"en la práctica, la pronunciación de un idionna, que hasta ahora se forma en cada individuo con acento local, en conversación con un reducido circulo de coterráncos, se formará mañana con acento universal; el trato material inmediato será lo de menos, ante las repeticiones de la radio fy la televisión] en cada hogar y en cada hora; el influjo cjemplar de la palabra radio - [y tele] - difundida, con fines tanto recreativos como educativos o didácticos, pesará más sobre el habla local de cada región; las variedades dialectales se extinguirán por completo* (Nuevo valor, p. 494).

2.3.2.I.2. $Y$ al colapso de vida intelectual de aquella época hay que oponer hoy la indiscutible actividad literaria de los pueblos hispanohablantes y valorar en su justa medida la importancia para la unidad lingüística del respeto que se tiene en todas las clases socio-culturales por la forma escrita:

"Una evolución fonética - nos ha demostrado don Ramón- tarda varios siglos en abrirse camino, en lucha con la lengua docta, y en nuestros tiempos tardará mucho más, pues las formas ortográficas tienen mucho más prestigio y poder que en los origenes, cuando la literatura no existia (ibid., p. 489).

1 Cp.: "Quizás estemos viviendo sintplemente los últimos dias del libro", GERARD Genietre, Estructuralismo y' critica literaria, B. Aires, Ldit. Universitaria de Córdoba, I967, pp. 55-56. 
2.3.2.I.3. Por otra parte, y a juicio sienupre de don Ramón, la unidad de nuestra lengua está asegurada también por el hecho de que nel español americano es hablado mucho más uniformemente aún que el peninsular" (Unidad, p. 215), debido a que "la colonización creó una cultura bastante igual en la inmensa extensión que hay desde Méjico hasta Chile y la Argentina" (ibid.), hasta el punto que "la lengua popular hispanoanericana es una prolongación de los dialectos españoles meridionales» (Colón, p. II5), vehículos de esta cultura, pues,

sel grueso de las primeras enigraciones salió del sur del reino [de Castilla]. es decir de Andalucia, de Iixtremuadura y de Canarias" (ibid.).

-I a conversación familiar de las personas educadas de la América cspañola cs, mirada en sus salientes rasgos, el habla culta familiar de Andalucia, teñida de algún vulgarismon (ibid., p. IIG).

Como se ve, en esta antigua disputa - aún no terminada - sobre "la base de la hispanidad americanan, Menéndez Pidal se abanderiza con la te $\mathrm{s}$ is and a $1 \mathrm{uc}$ ist a junto al propio Cuervo, a M. L. Wagner, Navarro Tomás, Entwistle, Lapesa, Boyd-Bowman y otros, contra la tesis del desarrollo lingüístico paralelo e independiente del español de América con respecto a influjos regionales peninsulares, tesis defendida sobre todo, como se sabe, por Pedro Henríquez Ureña. Es sintomático, en este sentido, el título de uno de los últimos trabajos de don Ramón sobre este tema: Sevilla frente a Madrid. Algunas precisiones: sobre el español de América ${ }^{1}$.

Queda claro, pues, que para él,

radmitidas ciertas divergencias [...], que existen, y mucho mayores, en todos los idiomas aun en los de menor extensión geográfica, no puede decirse que haya oposición entre lo castellano y lo hispanoamericano. Este antagonismo que algunos establecen y exageran, sea por sincera desorientación, sea por servir a intereses o pasiones particulares contra el puro interés humano, científico y literario, queda resuelto dentro de la unidad superior de la lengua española culta y literaria ?.

Ni siquiera las múltiples lenguas autóctonas del Nuevo Continente -en su opinión - han logrado ni lograrán amagar dicha unidad, pues las influencias atribuidas al sustrato indígena son mucho menores de

¿ Miscelánca Homenaje a Audre Martinet. Estructuralismo e Historia, III, Canarias, Univ. de la Laguma, I962, pp. 99-165.

2 I'rólogo a T. Natarko y A. M. Ispinosa, A Primer of Spanish Pronunciation, New York, I926, pp. x-xi. 
lo que generalmente se cree: no obstante que "la sintaxis y el léxico están mucho más abiertos que la fonética y la morfología a innovaciones y a influencias externas de toda clase» (Colón, p. I25),

4la barbarie de las lenguas indigenas y su enorme cantidad y fraccionamiento no son circunstancias propicias para que cualquier rasgo de sintaxis de esas lenguas suministre un extranjerismo de cierto crédito y extensión dentro del español» (ibid., p. II4),

y aunque, no obstante la tal "barbarie»,

*en el vocabulario, si, las lenguas indigenas iniluyeron mucho el habla colouval, apoyadas por la extraũeza de la vegetación, de la fama y de la geografia del nuevo mundo; [pero] las meras peculiaridades de vocabulario, y más si por lo general están destinadas a cbjetos naturales nuevos, no constituyen en modo alguno una diferencia que por si sola separe un grupo lingüistico» (ibid., p. I I5).

\section{Por lo que toca a}

la influencia de éstas [las lenguas incligenas] en la fonética del español, puede decirse que es despreciable; tan poca es que hasta alora no es per ceptible con claridad, (ibid., p. II4).

"Asi el futuro del idioma, en vez de amenazado por la negra nube de la fragmentación, lo prevemos llegar a una más perfecta unificación que la que ahora logray (Unidad, p. 205).

2.3.2.2. Al segundo considerando, la confianza absoluta en "la evolución fatal del lenguaje, incoercible en todos los tiempos y en todos los climas" ${ }^{2}$, don Ramón opone su certeza, también absoluta, de que

4la evolución del lenguaje está en manos de sus lablantes y depende de la atención o del descuido negligente con que miren la constitución y desarrollo del idioma que manejan. Todo es que los hablantes sientan la necesidad de emplear trabajo y esfuerzo en guiar la evolución del idioma, en favorecer una u otra tendencia, eu contener la propensión vulgar simplificadora, como se está conteniendo, muy débilmente por cierto, en la pérdida de la $d$ entre vocales. El resultado correctivo será completo, como se consiguió, volviendo atrás, después que la simplificación de los grupos consonainticos cultos había triunfado totalmente; después que coluna, dotor, conceto, etc. habian llegado a ser admitidos por los grandes poetas de los siglos de oro, cl iclioma retrocedió, desestimó esas formas, y las arrinconó entre la pobre turba analfabeta "de los que dicen diferiencia y haiga" (Nuevo valor, p. 493).

1 Culinvo, Obras II,p. 575. 
No se dude pues - parece decirnos Menéndez Pidal- de la eficacia de la labor de todos aquellos que, por el conocimiento no sólo práctico, sino teórico de su lengua, tienen la misión de llevar a los usuarios de la misma por los cauces de "la lengua literaria común [al mundo hispánico] [...], tipo único de referencia" (Colón, p. I25).

Es indiscutible para él que

-la voluntad correctiva consigue sobre el idioma todo lo que quiere, y no sólo subre la lengua escrita y sobre las clases educadas, sino solore toda la comunidad hablante" (Unidad, p. 203).

Lo muclio que se puede adelantar en este sentido, lo augura, entre otras, la circunstancia de que "la acción del individuo y de la colectividad sobre el idioma se va haciendo cada vez menos inconsciente" (ibid., p. 205), y al hablar de colectividad no pensamos necesariamente en organismos "ad hoc", dados a la tarea de velar por la unidad del español, pues,

asiempre más que en convenios e instituciones, la colesión se funda en la intinuidad espiritual $y$ material de los pueblos, en sus relaciones vitales, ell su literatura sobre todo" (ibid., p. 216);

y en favor de esta cohesión está el hecho de que "utoda la civilización hispanoamericana descansa principalmente en su base española, a veces con soiprendentes arcaísmos" (Colón, p. I2I). Esto, sin embargo, no significa negarle personalidad a los países hispanoamericanos:

-España [...] cada rez reconoce más ampliamente que cada pais americano es un valor que debe contar en la historia literaria $y$ lingülstica españoia. Pero al mismo tiempo que afirmamos estas personalidades, creemos que ellas consisten en variaciones de la cultura hispánica, aunque algunos renieguen de ella, victimas de prejuicios arcaicos; cultura hispánica, matizada de diversos modos en esas nuevas Españas, donde una común tradición se descompone, como la luz, en mil irisacionesı (ibid., pp. I22-23).

La "tradición", entonces, promotora y fortalecedora de la unidad. Esa nisma tradición que se revela en el hecho de que el romancero sea uprodigiosa y fecundan continuación de los poemas heroicos medievales ${ }^{1}$; en que se hayan tornado habituales sus constantes refundiciones y en que, como en las grandes catedrales del Medievo, sus autores hayan quedado para siempre en el anonimato.

No olvidemos que - según Nenéndez Pidal-

1 R. MIfenendiz Prdal. Flor meva de romances viejos, Col. Austral, núm. Ioo, octara ed., B. Aires, Espasa-Calpe, 1950, p. 15. 
"si se quiere definir con una sola palabra el carácter que más distingue la vida entera de los hispanos, esa palabra no podrá ser otra que t r a diciona 1 is mo" (Conde, M. P., p. 90).

\subsubsection{En conclusión,}

"así como no cabe hablar de ley nat u ral o de evolución fatal que traiga la muerte del idioma como de todo orgauismo viviente, tampoco cabe hablar de una le y históric a que traiga la fragmentación en vista de lo que con el latín sucedión (Unidad, p. I94).

Por todo lo dicho estimo que ningún elogio sería más aplicable a don Ramón que el que Ronjat hizo una vez a van Ginneken, upor la importancia que concede a la afectividad en su concepción del lenguaje, así como por su actitud juiciosa frente a los positivistas e idealistas, tomando todo lo bueno de cada escuela (el método seguro de los primeros y las visiones de conjunto de los últimos)" ${ }^{1}$.

\section{Epilogo.}

3.o. Creo que después de este bosquejo panorámico, por fuerza sumario y simplificador, de la magna labor lingüística, gramatical y filológica de Menéndez Pidal, expuesta siempre en una rprosa $[. .$.$] limpia,$ de una sobriedad y precisión desesperantes [que] nos alejan de la idea del erudito" ${ }^{2}$, se comprenderá el porqué de su enraizada influencia en la lingüística española. Si aún tuviera que sintetizar más, con decir que introdujo en España -y con ello en la Hispania cultural de nuestro siglo- los estudios científicos sobre nuestra lengua, y que ya no se podrá hacer ninguna investigación diacrónica que la tenga por objeto sin considerar lo aprendido en su obra o sin recurrir directamente a ella, quedaría todo dicho. Pero no escatimaré el relieve que merecen algunos hechos ya consignados y otros que será útil siquiera enumerar:

3.I. Por iniciativa suya se creó (Igro) la Sección Filología en el Centro de Estudios Históricos, del cual era Director, desde 1907, por encargo de la Junta de Ampliación de Estudios.

3.2. En IgrI fundó en Roma la Escuela Española de Arqueología.

3.3. Creó, en IgI4, la Revista de Filologia Española, la primera revista importante $-y$ una de las más importantes aún hoy- del

1 IORDAN, Ling., p. 152, nota 22.

2 Azorin. Lı Frensa, Buenos Aires, 9-XII-I928. 
mundo hispánico, dedicada a estudios lingüisticos, gramaticales y filológicos.

3.4. En I923 echó los cimientos del Instituto de Filología de la Universidad de Buenos Aires.

3.5. Enriqueció la bibliografía filológica española con una gran cantidad de ediciones anotadas, críticas y paleográficas.

3.6. Elaboró una visión totalizadora de la cultura medieval española, a través de su lengua, empujado por el mismo sentimiento romántico que lo llevó a amar la Naturaleza y la poesfa tradicional, y a hacer un dogma del individualismo.

3.7. Ya en su época juvenil, dio a conocer en España, entre otros, a Federico Díez, autor de la Grammatik der romanischen Sprachen, considerado iniciador del estudio histórico de la lengua castellana ${ }^{1}$, y a Hugo Schuchardt, romanista y lingüista general, "quien, siguiendo una dirección opuesta a la de los neogramáticos, considera el lenguaje en estrecha relación con la etnografía y la civilización de los pueblos, uniendo al método histórico el descriptivon ". Claros antecedentes de la labor investigadora de don Ramón, quien coincide con Schuchardt, además, en su interés por el folklore.

3.8. Con su Orígcnes del español se inicia en España la prehistoria lingüistica, unna nueva rama de la ciencia lingüistica que, mediante la etimología y la toponimia, penetra en tiempos muy renotos" 3 .

3.9. Introdujo en la Península la geografía lingüistica, enriqueciéndola con los métodos "geográfico-excursionístico" y cronológicogeográfico de su creación ", métodos que aplicó también a la geografía folklórica, dada a conocer igualmente por él.

3.Io. Fue el padre espiritual del Atlas Lingiiistico de la Peninsula Ibérica, primer intento de cartografiar las lenguas románicas de la Penf́nsula.

3.Ir. Expuso y defendió su teoría de la colonización suditálica de España, con la que logró iluminar más de un aspecto de la historia del español.

3.I2. Expuso y desarrolló su teoria de la colonización sudhispánica de nuestra América como factor determinante de las modalidades lingüisticas distintivas del español de "esta otra España».

1 Cp. F. Hanssin, Gramática histórica de la lengua española, Halle, Max Niemeyer, 1013, p. I.

2 G. Thomsion, Ilistoria de la lingätstica. Batcelona, Iabor, 1945, p. 155.

3 Tovar, Ling. y' filol., p. II7.

- A. Alonso, RFH, 19.4, VI, p. 404 . 
3.13. Declaró reiteradamente su confianza inquebrantable en la voluntad humana $\mathrm{y}$, por ello, en la prolongación hacia el futuro de la unidad actual de la lengua española; expresión de un deseo muy hondo de ver consolidada para siempre la unidad espiritual del mundo hispánico.

3.I4. Defendió y practicó la concepción idealista del lenguaje, "quizás más a lo Schuchardt que a lo Vossler» (ibill.), pero sin olvidar el rigor cientifico del positivismo metodológico.

3.15. Expuso, defendió y aplicó su teoría de la plurisecular duración de los procesos lingüísticos, teoria intimamente ligada al tradicionalismo, como rasgo constitutivo de la vida de nuestra lengua, y de la vida toda española.

3.I6. Como otra contribución, aportó a la lingüística general su. teoría del estado latente de los procesos de cambio e innovación antes de afianzarse en la lengua literaria, con lo que dignifica lingüisticamente a "los de abajo».

3.I7. Defendió y probú con su obra, "desde el principio de su carrera" (ibid.), la interdependencia existente entre filología y lingüistica, entre lingüística y literatura, $\mathrm{y}$ entre lingüística y folklore, hasta el punto de aplicar con extraordinario acierto los métodos de la lingüística al estudio de la poesía tradicional - que no es lo mismo que (populan ${ }^{1}$-, poesía en buena medida descubierta por él, animado por el mismo impulso romántico que hizo de Herder un udescubridor de las canciones regionales» ${ }^{2}$.

3.I8. Consecuente con su concepción dinámica del lenguaje, abogó con mucha sabiduría por un equilibrio normativista en el uso de la lengua, entre dos excesos: un purismo intransigente y esterilizador, y una condescendencia libertina y desquiciadora.

3.I9. Toda su obra es testimonio perenne de su sentido profundamente humano del quehacer científico, que lo llevó a apasionarse no sólo por sus teorías, sino también por los objetos a partir de los cuales

1 "La poesia p o p u l a r - según sus palabras- es poesía de un autor que se siente pueblo; la poesia $t$ r a d i c i o n a l es poesia de un pueblo que se siente o que se hace autorn (CONDE, $M . P .$, p. IO4).

2 Kror., Filol., p. I 4 r. "Al fin del siglo xvirr y comienzos del XIX, los románticos atribuian a la pocsía popular un carácter excepcional en alto grado; percibian en ella la expresión del alma del pueblo en su plena espontaneidad, en su naturalidad incorrupta (IIerder), en su inocente pureza, propia de la feliz infancia de la humanialad (Grimm), una maturaleza fresca, primordial, incomparable (IIegel)..." (Musíndiz P'Idar, apud CONdE, M. P.. p. r05). 
las configuró. Sus estudios de las "gestas" son, sin duda, otras tantas gestas.

3.20. Su vida, enteramente consagrada a la investigación y a la docencia, reveló una increíble capacidad de trabajo creador, sólo comparable con la de Menéndez y Pelayo en Iispaña, y con las de Bello y Cuervo en nuestra América.

3.21. Como era de esperar, creó con su ingente labor, desde la cátedra y el libro, toda una escuela lingüística ${ }^{1}$, a la cual pertenecen los mejores representantes de la lingüistica y la filología españolas contemporáneas.

3.22. Así pues, directamente con su obra y su cátedra, e indirectamente a través de sus discípulos y de los discípulos de sus discípulos..., este gigante de la lingüística orientó y sigue orientando todos los estudios relacionados con el español en el mundo hispánico, donde además nos ha dejado la inmensa enseñanza de lo que puede hacer la férrea voluntad de un hombre cuando cstá acerada por una arrolladora vocación: la vocación mesiánica de macstro.*

\section{Amibrosio Rabanales}

Universidad de Chile

Se incluyen en esta clave bibliográfica, sólo las obras citadas abreviadamente. Los uúmeros remiten a las notas al pie de página en que se proporciouan los datos completos.

Bello, Gram., p. 28r, 11. 3; Conde, $M . P$. p. 226, u. 5; Cuervo, Obras $I$, página 282, 11. I; Cuervo Obras $I I$, página 282, 11. I; Gazdaru, Controv., página 239, n. I; Iordan, Ling., p. 238, n. 2; Kroll, Filol., p. 265, n. r; Leroy, Courrants, p. 239, n. 3; Righi, Filol. página 264, n. I; Rohliss, Manual, página 226, น. 2; Saussure, Curso, p.
233, 11. r; Tovar, Ling. y Filol., p. 23r, 11. I.

\section{Obras de Menéridez Pidal:}

Cantar I, p. 244, n. 2; Cid, p. 272, n. 9; Colón, p. 24I, n. I; Dicc., p. 245. n. I; Encicl., p. 230, n. 4i España II, página 240, n. 4; Griera, p. 238, n. 5; Leonés, p. 226, n. 3i Leyenda, p. 25I, n. 3; Manual, p. 234, n. I, p. 255, n. 4; Modo, p. 23r, n. 2; Nuevo valor, p. 28r. n. 2; Origenes, p. 226, n. 8; Reliquias, p. 266, n. 11; Toponimia, p. 220, n. 4; Unidad, p. 28r, n. I.

1 Cp. Drego Cataláx, La escuela lingüistica española y su concepción del lenguaje, Madrid, Gredos, 1955. 